\title{
Technology Choices in the U.S. Electricity Industry before and after Market Restructuring
}

\author{
Zsuzsanna Csereklyei* and David I. Stern**
}

\begin{abstract}
We study the drivers of the adoption of electricity generation technologies between 1970 and 2014 in the lower 48 U.S. states. Since the 1990s, major electricity market restructuring took place in some parts of the United States. We explore the implications of changing from a regulated "cost-of-service", or rate of return, system to liberalized wholesale electricity markets on technology and fuel choices. We find that wholesale market restructuring resulted in significant immediate investment in various natural gas technologies due to higher expected profits, and a reduction in coal investments. In states that adopted liberalized wholesale electricity markets, higher natural gas price expectations resulted in more investment in coal and renewable technologies, while higher coal price expectations resulted in lower coal-fired baseload power investments. Natural gas price expectations, therefore, have the potential to significantly shape the power generation landscape of the future.
\end{abstract}

Keywords: Technology choices, Electricity industry, Market restructuring

https://doi.org/10.5547/01956574.39.5.zcse

\section{INTRODUCTION}

We examine the drivers of investments in specific power plant technologies in the U.S. between 1970 and 2014, with a special emphasis on investment choices before and after electricity market restructuring. Technologies vary according to fuel type, whether they play a baseload, peaking, or intermittent role in the system, and energy efficiency. While the majority of studies claim that operational efficiency of power plants improved following deregulation, very little is known about the impact of deregulation on the fuel choice and technical efficiency of new electricity generation investments.

Past research on the effect of market liberalization on the efficiency of the U.S. electricity industry has mostly focused on the effects on existing power plants (Wolfram, 2005; Borenstein and Bushnell, 2015; Fabrizio et al. 2007). Borenstein and Bushnell (2015) note an overall positive influence of restructuring on power plant operations. Davis and Wolfram (2012) found that deregulation was associated with about a $10 \%$ increase in operating performance at nuclear power plants, due to higher capacity utilization. Craig and Savage (2013) find that full electricity market liberalization (access to both wholesale and retail markets) increased the technical efficiency of investor-owned plants by about $9 \%$, due to improvements in technologies and organizational practices. They find further evidence that such efficiencies may have spilled over to the public sector.

* Corresponding Author: School of Economics, Finance and Marketing, RMIT University, B80, 445 Swanston Street, Melbourne VIC 3000, Australia. E-mail: zsuzsanna.csereklyei@rmit.edu.au, Phone: +61 399251518.

** Crawford School of Public Policy, The Australian National University, 132 Lennox Crossing, Acton, ACT 2601, Australia. E-mail: david.stern@anu.edu.au. Phone: +61-2-6125-0176. 
Recent research investigates the partially irreversible decisions to start up, abandon, or shut down electricity production assets in the U.S. (e.g. Fleten et al., 2017; Fleten and Näsäkkälä, 2010). Using a sample of 1121 generators for the period 2001-2009, Fleten et al. (2017) find that regulatory and profitability uncertainty reduce the probability of shut down, while regulatory uncertainty reduces the probability of startup as well. While the investment decision process of irreversible investments under uncertainty is well documented in finance and microeconomics (Caballero and Pindyck, 1996; Bloom et al., 2007), we are not aware of research that focuses on the effect of liberalization on the fuel and technology choice of new power generation investments, which is the focus of this paper.

While the long-term rate of return of investment in power generation does not depend on electricity prices, fuel prices, or technology choice under a cost-of-service regime, the rate of return depends on all these factors in a liberalized regime with wholesale markets. We use state level and ISO/RTO level panel datasets to investigate the factors that affect new investments in the various electricity generation technologies. We find that in states that adopted liberalized wholesale electricity markets, higher gas price expectations result in more investment in coal and renewable technologies and less investment in gas generators, while higher coal price expectations result in lower coal-fired baseload power investments. Natural gas price expectations, therefore, have the potential to significantly shape the power generation landscape of the future.

The paper is structured as follows: the next section introduces relevant background information on changes in policy and the factors affecting investment decisions in the power generation sector. The third section presents the model and the data and the fourth section our results. The final section provides conclusions and discusses the possible policy implications of our results.

\section{BACKGROUND AND THEORY}

\section{A. U.S. Energy and Environmental Policies}

Following the 1973-74 oil crisis, the choice of power technologies for new investments saw a marked change. There was a shift away from oil-fired generators towards primarily coal, small-scale hydro, and to an extent, nuclear energy, even though after the Three Mile Island (TMI) accident in 1979 there were no new nuclear investments for several decades. Nuclear accidents are known to cause negative external shocks in new nuclear power investments locally (Csereklyei, 2014). Energy security considerations led policymakers to support the shift to new energy sources with legislation. The Public Utility Regulatory Policies Act of 1978 (PURPA) created legal categories for "qualifying facilities", and independent power producers (IPPs). The National Energy Policy Act of 1992 subsequently allowed utilities to "enter the IPP business as exempt wholesale generators, or EWAGS. This allowed IOUs (investor-owned utilities), through subsidiaries, to develop power plants to sell power to other utilities" (Warwick, 2002, p 3.10). These regulations set the legal background enabling federal electricity market liberalization.

Figure 1 depicts selected key technology capacity additions in the U.S. The graph shows several distinct periods of investment in different fuel choices and technologies. While nuclear power and pulverized coal dominated additions to the grid from the 1970s to the mid 1980s, the period after 2000 was characterized by investment in natural gas base- and peak-load capacity. From 2005 onwards, we can also observe increased additions of renewable energy including onshore wind turbines and solar photovoltaic generation. Investment in coal technologies strongly declined over time, due to changes in power plant fuel regulations, more stringent EPA rules, such as the Coal 


\section{Figure 1: Key technology additions to U.S. electricity generation capacity, measured in MW} nameplate capacity, 1970-2014.

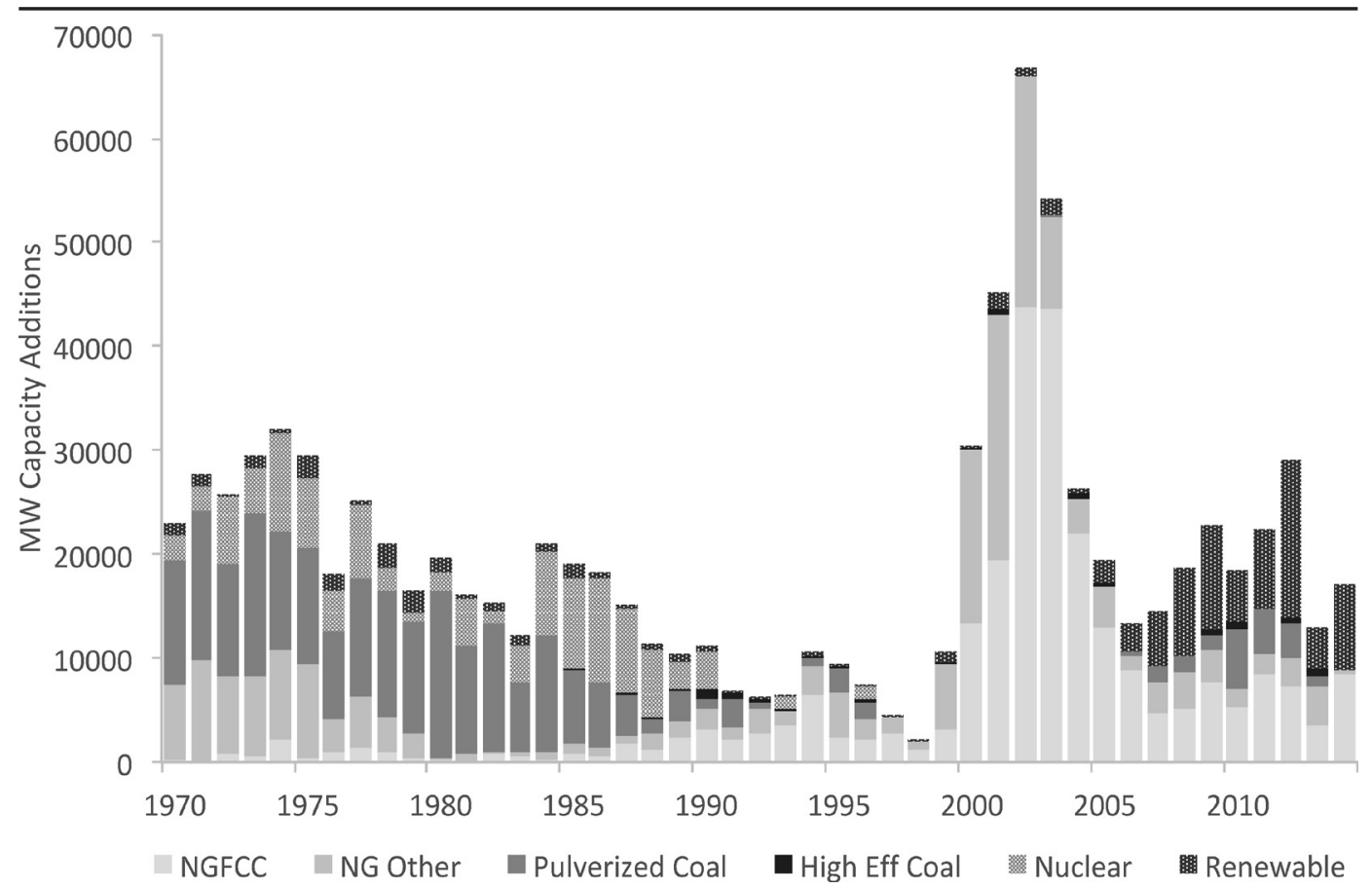

Notes: The technologies in the graph are defined as follows, with the variable names used in our quantitative analysis in capitals: "NGFCC" covers natural gas-fired combined cycle plants; "NG Other" includes natural gas-fired combustion turbines (NGFCT) and natural gas steam turbines (NGST); "Pulverized Coal" includes conventional steam coal-pulverized coal technology (CSC-PC); "High Efficiency Coal" includes conventional steam coal-fluidized bed technology (CSC-FB) and coal integrated gasification combined cycle technology (CIGCC); "Nuclear" includes nuclear energy (NUC); "Renewable" includes conventional hydroelectric (CHYD), solar photovoltaic (SPV), and onshore wind generation (OWT).

Source: Form 860-Y2014 (EIA, 2016a).

Combustion Residuals Rule, the requirement of emission control devices to comply with Mercury and Air Toxics Standards (MATS), and declining profitability caused by market structure changes (DOE, 2017).

Natural gas regulation has also had a strong direct effect on electricity generation investments. The development and future expectations of natural gas prices have been crucial in driving technology adoption in the past two decades, as natural gas tends to be the fuel determining the marginal cost of electricity supply in the majority of deregulated electricity systems (Borenstein and Bushnell, 2015). Effective natural gas price controls in the U.S. go back as far as the 1950s (Joskow, 2003). These regulations, however, resulted in an acute undersupply of natural gas by the mid1970s (Joskow, 2003). The Natural Gas Policy Act of 1978, which was passed partly as a response to shortages in natural gas, deregulated the supply of new gas, by essentially eliminating price caps (Warwick, 2002). This resulted in increased gas production and falling prices starting in the mid 1980s. On the other hand, the Powerplant and Industrial Fuel Use Act of 1978 (FUA) prohibited the use of natural gas or petroleum as a primary energy source for baseload power plants, unless an exemption was obtained from the DOE. Partly because of this, while natural gas prices were falling, demand stayed relatively low. The FUA was repealed in 1987. As a final step, restrictions on the wellhead price of natural gas were entirely removed by the Natural Gas Wellhead Decontrol Act of 1989 (Joskow, 2003). 
Figure 2: Real coal and real natural gas prices in the electric power sector (U.S. average).

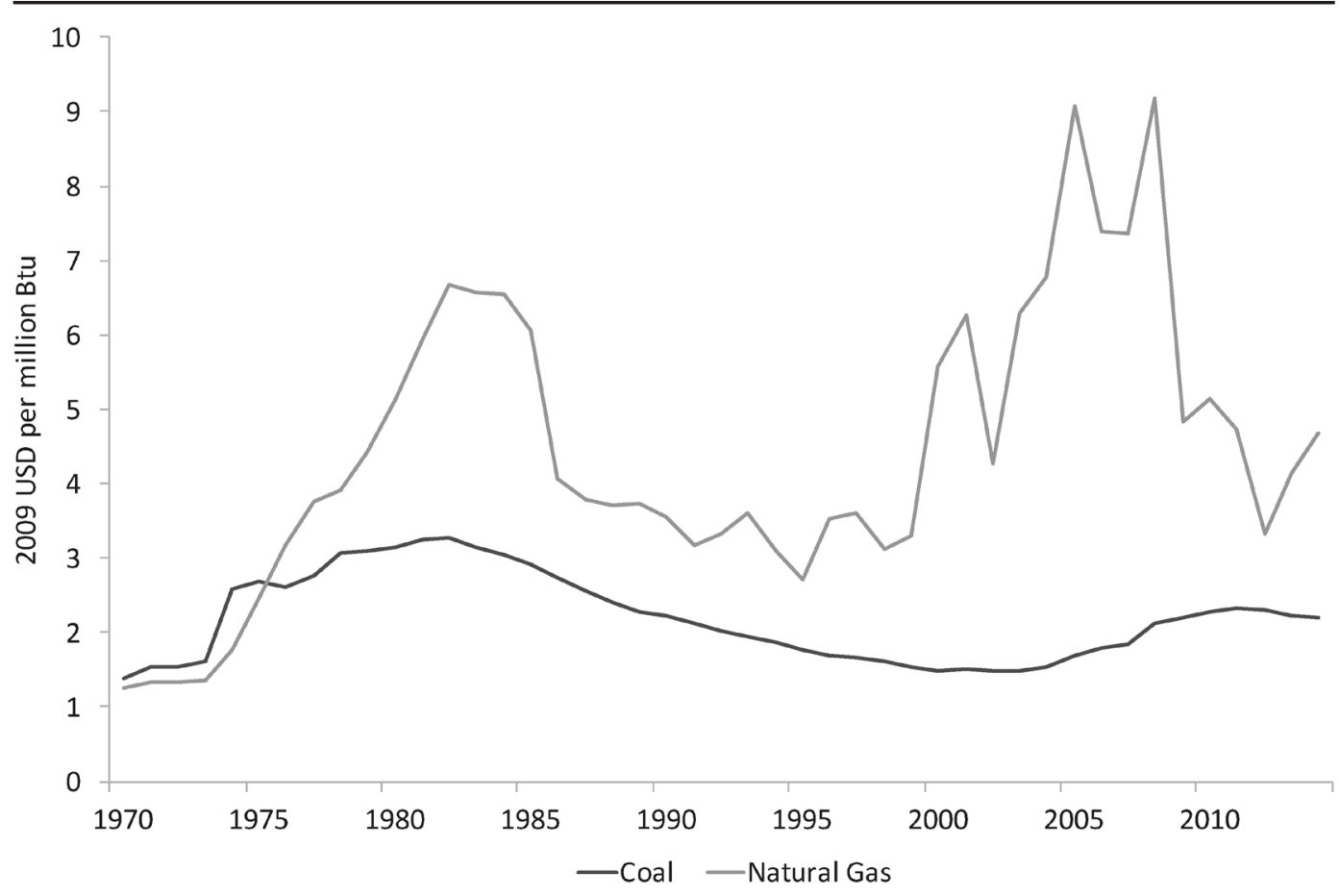

Source: EIA State Energy Data System (EIA, 2014), expressed in real dollars per million Btu.

Figure 2 shows the development of average real coal and natural gas prices over the past 45 years. The real level of prices has not drastically increased since the late 1970s, though natural gas prices have been very volatile.

By the end of the 1980s, the major obstacles facing gas exploration and production were regulated pipeline transportation rates and the pipeline companies' control of end user prices (Warwick, 2002). FERC Orders 436 and 500 aimed at introducing competition into the pipeline industry, while maintaining federal regulation of the transportation function. FERC Order 636 in 1992 then finally restructured the gas industry by requiring pipeline companies to "open their capacities to any and all transporters and unbundle their transportation service so as to allow customers to select supply and transportation" at will (Warwick, 2002, pA.16). As a result, gas exploration soared, and by 1996-1997 prices fell considerably. The electricity market reform was initiated under these circumstances.

Changes in environmental regulations also tend to influence technology choices and the evolution of technology. Federal environmental regulations and emission standards are administered by the EPA and are binding on all states. Most major environmental laws in the U.S. were passed in the 1960s and 1970s, including the Clean Air Act and Clean Water Act, with some amendments following in the 1990s. Relevant regulations with recent compliance deadlines include the Mercury and Air Toxics Standards (MATS), Clean Water Act Section 316(b), and the Coal Combustion Residuals rule (DOE, 2017). Notably, states may apply for waivers in order to enact stricter than federal laws. For example, with respect to greenhouse gas emissions from electricity generation, California initiated a statewide standard (Senate Bill 1368) applicable to new investments and renewals (California Public Utilities Commission, 2007). Oregon, Washington, and New York passed 
similar emission standards, ${ }_{1}^{1}$ while Montana and Illinois incentivize or require $50 \% \mathrm{C}_{2}$ capture for new plants.

\section{B. Electricity Market Regulation}

The economic and political incentives for electricity market restructuring thus originate in a period of historically low gas prices as well as high reserve generating capacity that resulted in much higher average than marginal cost of electricity generation in most parts of the United States (Borenstein and Bushnell, 2015). Before market restructuring efforts began in the late 1990s, the U.S. electricity industry was characterized by a cost-of-service model, in which the regulator set electricity prices in a manner that allowed IOUs to recover their "prudently-incurred operating costs and a regulated return on capital investment" (Borenstein and Bushnell, 2015, p438). By contrast, price setting in liberalized wholesale electricity markets is generally based on equilibrium between supply and demand, where the price is at or above the marginal production cost of the last supplier needed to satisfy demand (Borenstein, 2000). If the average cost of electricity generation (based on the entire portfolio of base- and peak-load generators running on different fuels with different capital costs) is significantly higher than the marginal cost (defined as the marginal cost of the generating unit which is dispatched last), strong economic incentives would exist in favor of market liberalization at the generation level. Therefore, as Borenstein and Bushnell (2015) claim, political sentiments towards market liberalization are best described by "comparing average to marginal costs."

Electricity market deregulation may occur with regard to four different stages in the supply of electricity to consumers: "the generation of electricity, long distance transmission, voltage step down, and local distribution to end users and retailing" (Borenstein and Bushnell, 2015, p439). Wholesale market restructuring is regulated on a federal level, and is thus not in the jurisdiction of individual states. Wholesale market liberalization in the U.S. began with FERC Orders 888 and 889 , which endorsed the concept of independent system operators (ISOs). FERC Order 2000 encouraged utilities to form or to join RTOs or regional transmission organizations (FERC, 1999). Most existing ISOs/RTOs were formed by pre-existing power pools in the late 1990s and early 2000s. Theoretically, utilities have the choice to form or to join an ISO or RTO all over the United States. However, states have a strong influence over their utilities, and thus can exert pressure by even breaking up utility monopolies to encourage market entry. Therefore, the transition to wholesale competition was most likely to occur in regions or states where the average cost of generation was above marginal cost, such as the North-East, Illinois, Texas, California, and Montana (Borenstein and Bushnell, 2015). Regions with comparatively low electricity rates at the end of the 1990s, such as the Southeast or the Northwest largely resisted restructuring efforts.

Following Craig and Savage (2013), we can distinguish between partial and full competition in electricity markets, defining the first as access of new entrants to wholesale markets (ISOs or RTOs), and the latter as access to both wholesale and retail markets. The liberalization process in the United States went ahead mostly in electricity generation, culminating in the divestiture of a large number of IOUs and in the market entry of new generation capacity provided by independent

1. Oregon: Oregon's Carbon Dioxide Emission Standards for New Energy Facilities: https://digital.osl.state.or.us/islandora/object/osl:6869m. Washington: Washington State Legislature, Chapter 80.70 RCW: http://apps.leg.wa.gov/rcw/default. aspx?cite=80.70\&full=true. New York: New York Codes, Rules and Regulations: 6 CRR-NY III A 251, https://govt.westlaw. com/nycrr/Browse/Home/NewYork/NewYorkCodesRulesandRegulations?guid=I5d3c9d90eafb11e19f380000845b8d3e\& originationContext=documenttoc\&transitionType=Default\&contextData=(sc.Default). Illinois: Public Act 095-1027: http:// ilga.gov/legislation/publicacts/95/PDF/095-1027.pdf. Montana: House Bill 0025.05, http://leg.mt.gov/bills/2007/billpdf/ HB0025.pdf 
power producers (IPPs). Borenstein and Bushnell note that the share of electricity generated by IPP generators increased from $1.6 \%$ to $35 \%$ from 1997 to 2012 . On the other hand, retail market liberalization falls under the jurisdiction of the individual states, which can decide on the introduction of retail market restructuring, suspend, or even reverse such efforts, as for example in the case of Arizona, California, or Virginia (Morey and Kirsch, 2016).

In liberalized wholesale electricity markets, natural gas prices thus began to largely determine electricity prices (DOE, 2017), as fuel costs comprise approximately $80 \%$ of the variable costs of natural gas-fired power plants (Craig and Savage, 2013). Following both natural gas and electricity market liberalization, the number of new natural gas generators (mostly natural gas combined cycle plants, and natural gas combustion turbines) skyrocketed, compared to other generation sources. However, as natural gas prices drastically increased by the second half of the 2000s, the building of new natural gas-fired power plants dropped considerably. During this period, the marginal profit of firms using energy sources other than natural gas was far higher than before restructuring.

This phenomenon, coupled with the California electricity crisis of 2000-2001 (Joskow, 2001; Bushnell, 2004) has in many cases reversed the relationship of marginal and average costs (Joskow, 2008) and led to the suspension of retail market restructuring activities in U.S. markets (Craig and Savage, 2013).

\section{Factors Driving Power Plant Investment Decisions}

Investment in power generation infrastructure and capacity is a long-term commitment that may take several decades to break even. The expected return on such investment will be determined by the discount rate and future operating costs and revenues, all of which are uncertain. While capital costs are predictable to a good extent — even though large projects tend to be over-due and over-budget (Flyvbjerg, 2014) — the future operating expenses of a thermal power plant are mostly determined by the cost of its main fuel and the efficiency with which it uses that fuel, while total average cost depends crucially on capacity utilization and initial capital costs. ${ }^{2}$ Future revenues, and therefore, the profit maximization strategy to be used, are determined by the regulatory regime in place and demand. In deregulated markets, the market price of electricity generated will be the key factor determining revenues (Joskow, 2011). Joskow (2011) notes that the market value of electricity may differ considerably in peak vs. off-peak hours, therefore, some energy generating technologies such as solar panels might produce much higher value electricity than others, such as wind turbines.

Under cost-of-service regulation, changes in costs due to changes in fuel prices or technology will be reflected by the end-user price (and thus revenues) and easily passed onto the customer. Such potentially higher end-user energy prices might lead to technological innovations and to efficiency improvements in end-use equipment (Ley et al., 2016; Popp, 2002; Newell et al., 1999).

There is mixed evidence on whether utilities in regulated regimes will invest in high efficiency but higher cost technologies or not, given a guaranteed return on capital investment and the coverage of operating costs. Averch and Johnson (1962) suggested that monopolies under rate of

2. In competitive markets, the ultimate decision on whether to invest in a generation unit will be determined by the expected return on investment. While the levelized cost of the energy generating technology (LCOE) and the levelized avoided cost of electricity (LACE) (Covert et al., 2016, Rhodes et al., 2016; EIA, 2016b) are often used as the measures for comparing the competitiveness of technologies, Joskow (2011) points out that the LCOE measure is flawed as it disregards the value of the electricity generated by intermittent vs. dispatchable sources, which depends on the variations in electricity price. Joskow (2011) thus suggests that in order to evaluate the economic attractiveness of a technology we need to take into account the expected market value of generated electricity and the total life-cycle costs, and then calculate the resulting associated profitability. 
Figure 3: Subcritical, supercritical, and ultrasupercritical steam coal generation investments, 1970-2014.

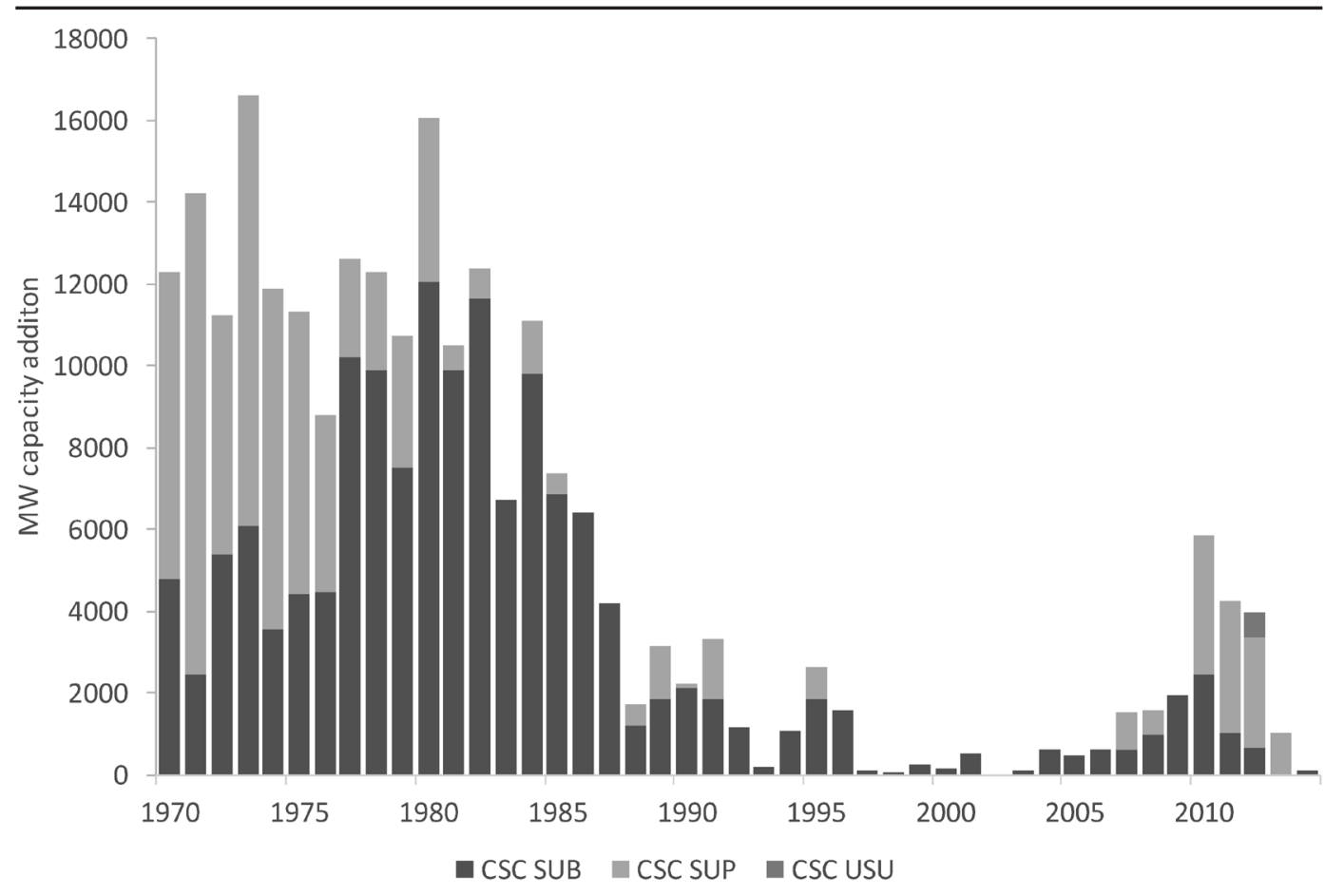

Source: Form 860-Y2014 (EIA, 2016a).

return regulation would overcapitalize rather than implement a cost-minimizing input mix. While some papers present strong evidence against this finding (Dechert, 1984), recent studies conclude that there is just too little evidence to suggest the presence or absence of the Averch-Johnson effect (Law, 2014). Additionally, there might be a disincentive for regulated utilities to invest in efficient technologies, because such innovations might reduce the total average cost of electricity generated, and, therefore, the regulated profits the utility is earning. Even if an incentive persists to overcapitalize, it is questionable whether a utility would choose to overcapitalize using the most efficient technologies.

A good example of decreasing energy efficiency under regulated markets is the switch from mainly supercritical to subcritical coal power during the 1970s and 1980s. Yeh and Rubin (2007) note that the thermal efficiency of new U.S. coal plants declined in the 1980s, due to the "demise" of supercritical plants, that were popular in the late 1960s and 1970s, with almost two thirds of the new generators built between 1970 and 1974 being supercritical (Figure 3). ${ }^{3}$

Under deregulated wholesale markets, however, the relative profitability of one type of power plant over the other can decide between survival and bankruptcy. Plants with lower marginal costs receive a higher place on the dispatch ranking, and, therefore, make relatively higher operating profits due to both their greater price-marginal cost margin and a higher frequency of supply (Craig

3. The reasons for abandoning higher efficiency plants were found in lowered demand for new plants in the 1970s, and technological problems leading to large operating and maintenance costs (Yeh and Rubin, 2007). Lowered demand for new electricity investments usually favored smaller, subcritical investments. Recent developments have, however, seen a moderate increase in supercritical plant construction in the U.S. In general, however, the majority of the U.S. coal fleet was built in the 1970s and 1980s, and thus is decreasing in efficiency due to age (Campbell, 2013). 
and Savage, 2013). Of course, plant owners still have to recover initial capital expenditures and ongoing interest payments. Often, low marginal cost technologies have higher capital costs. Natural gas-fired combined cycle power plants - usually used for baseload supply - might, for example, have higher capital expenses, but lower marginal costs than natural gas-fired combustion turbines, which are used for peak supply. As currently both base- and peak-load supplying generation are necessary for a functioning electricity system, technologies and fuels compete with each other across these categories in a competitive wholesale market system.

Therefore, while in regulated markets there is an, at best, questionable economic incentive to invest in high-efficiency technology, competitive liberalized markets should in theory encourage such investments. Highly efficient generating units have, thus, the potential to significantly reduce fuel input costs, and, hence, operating expenses and bidding prices. In practice, however, market imperfections arising from the regulatory and financial uncertainties surrounding deregulated markets, including potential market redesign, limits and caps on wholesale prices imposed by the regulator, and system operators' reliability actions that depress market prices discourage private investments in the power sector (Joskow, 2008). In particular, U.S. markets were designed with quite low wholesale price caps in order to limit the exercise of market power, but "these efforts to mitigate market power in the short run may create adverse generation investment incentives in the long run" (Joskow, 2008, 23). This investment disincentive especially affects investments in peak-load capacity that rely on high wholesale market prices to support investment costs based on limited capacity utilization. Thus, energy-only markets, as typically constructed, result in insufficient investments in generating facilities (Joskow, 2008; Knittel, 2015).

Thus, the development of fuel prices is crucial in competitive wholesale (liberalized) markets for three reasons. First, they are the main factor determining the operating cost of the plant. Second, natural gas prices tend to drive the wholesale electricity price (DOE, 2017) and, therefore, the price-cost margin is determined by the difference between different fuel costs. Finally, they heavily influence the capacity utilization of existing power plants.

Capacity utilization is another key factor determining the viability of a plant. Besides the price that the operator is willing to bid at, it is influenced by other capacity available, by the development of electricity demand, and in the case of wind and solar power by resource availability. The EIA (2016c) reports that during the period of high natural gas prices in 2005-2008 utilities would only run natural gas-fired combined cycle plants, after the maximum coal capacity had been exploited. As some plants are designed for base-load and others for peak-load, start-up investment costs might be correlated with future capacity utilization of a plant, while actual utilization will depend firstly on the development of electricity demand and available spare capacity, and secondly on the market prices of fuels in an open market, in particular natural gas. For example, at the time of writing, following lower market prices for natural gas, the utilization of natural gas plants has again increased. ${ }^{4}$

When investors form their expectations about future prices ${ }^{5}$ in the investment planning process, they might use information about the price development of the past few years, long-term

4. The EIA (2016c) reports capacity factors for the U.S. natural gas combined cycle fleet to have risen from $35 \%$ in 2005 to about $56 \%$ in 2016 . At the same time, the average coal fleet utilization declined in the long run from around $70 \%$ in 2005 to about 55\% in 2016 (EIA, 2016c). Renewable resources run at lower capacity utilization on average, with $33 \%$ reported for wind, $29 \%$ for solar photovoltaic, and $23 \%$ for solar thermal generators (EIA, 2016d).

5. While real fuel prices have been stationary over 40-50 years, there are decadal periods of consistently increasing and decreasing prices, that we assume influence decision-making. 
Figure 4: EIA short- and medium-term price forecasts for natural gas and coal starting in 1979.

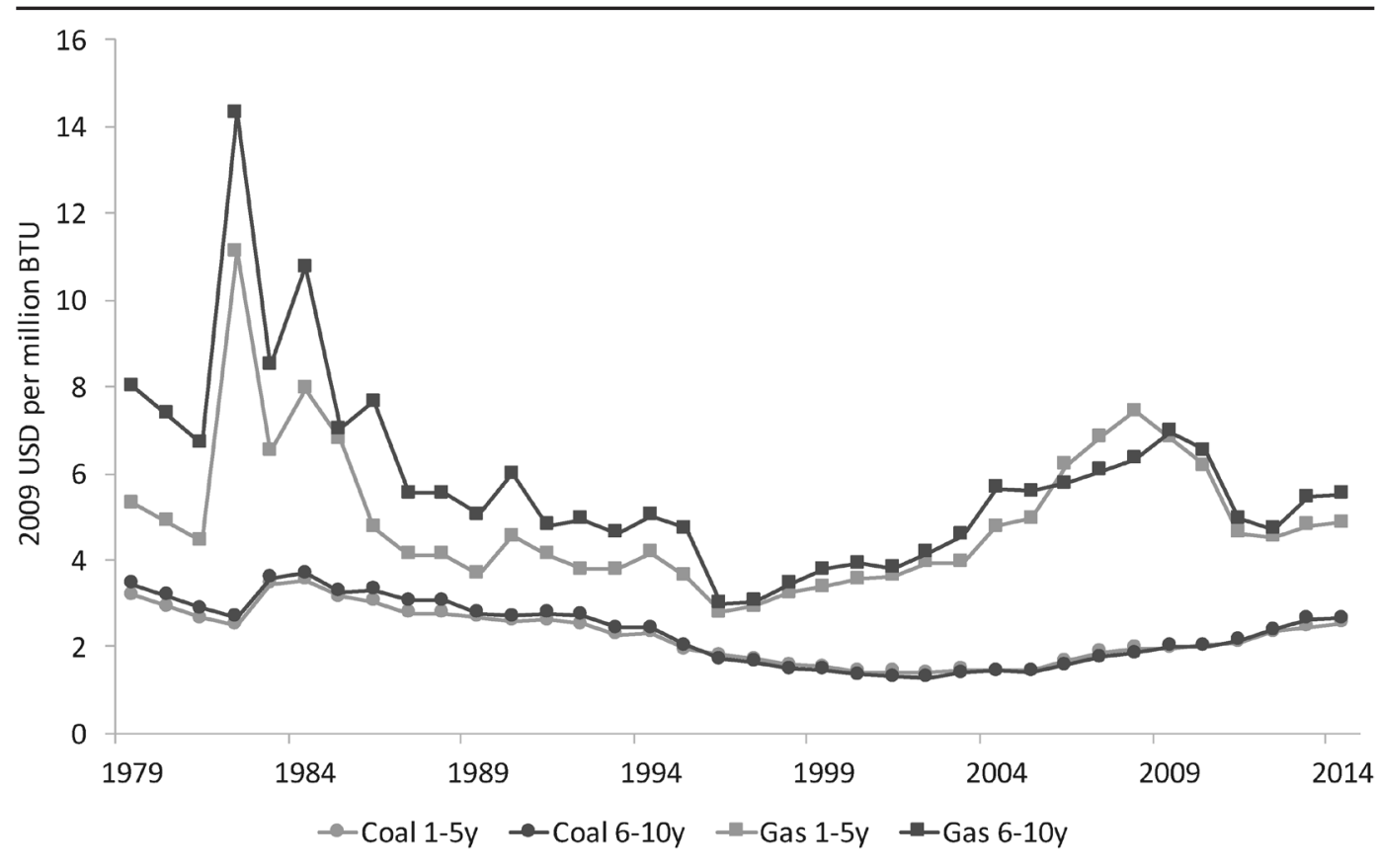

Source: EIA Annual Energy Outlook (EIA, various years).

price forecasts from the Energy Information Administration, or shorter-term expectations based on futures prices. Also, in energy markets there may be short-term shortages, such as that caused by Hurricane Katrina, which result in prices being higher than they are expected to be in the long term. As we have seen following the oil crises or the shale gas boom, expectations about natural resource prices are often wrong. Despite this, such expectations formed by market participants should play a crucial role in investment choice. Previous research has argued that the massive build-out of natural gas generation capacity in the late 1990s and early 2000s was not only due to natural gas and electricity market deregulation, but also to low EIA price forecasts and industry expectations.

If markets are efficient, current prices of financial assets and commodities reflect all presently available information about their value so that research that attempts to forecast prices will show very little success (Timmermann and Granger, 2004; Hamilton, 2009). Figure 4 shows the short-term (1-5 year) and medium-term (6-10 year) price forecasts assuming the "base scenario" for coal and natural gas, as published by the EIA starting in 1979. The short- and medium-term forecasts show remarkably little difference throughout this period. Comparing expected future prices (6 to 10 years ahead from the year of publication) and current prices in Figure 5 shows that expected prices follow current developments very closely. None of the great price hikes or drops in price could be predicted. As an example, the expected 6 to 10-year-ahead natural gas prices were as low as current prices at the end of the $1990 \mathrm{~s}$ - a forecast that proved very wrong. Then, when natural gas prices were extraordinarily high in the middle of the 2000 s, so were medium-term expectations. No one foresaw the drop in prices that followed soon after. These developments support the Efficient Market Hypothesis. Therefore, we use both the EIA's forecast expected prices and recent observed state-level prices as models of price expectations. 
Figure 5: Comparison of real natural gas and coal prices with EIA's mid-term price forecasts.

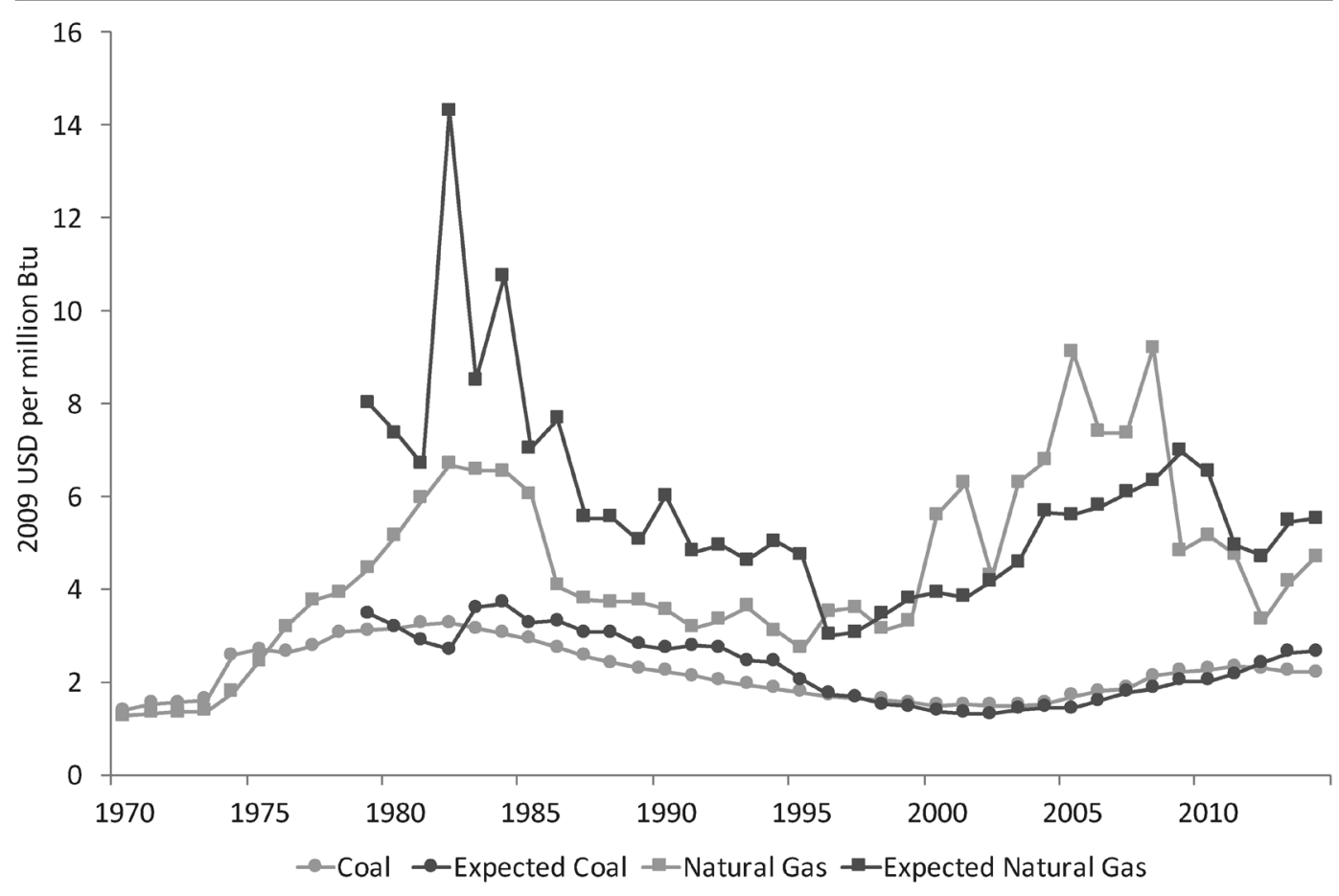

Notes: The forecast value in a given year refers to the expected prices 6-10 years from that year.

Source: EIA Annual Energy Outlook (EIA, various years); EIA State Energy Data System (EIA, 2014).

\section{MODELS AND DATA}

\section{A. Models}

The question this paper answers is: What drives the building of certain types of power plants, defined as a combination of fuel and technology? In particular, how do own and substitute fuel prices under regulated and liberalized markets impact on the choice of fuel and the efficiency level of the new plant? And most importantly, is there a discernable impact of electricity market reform on the construction of different types of generating units?

We test the hypotheses introduced in the previous section about expected fuel prices and market liberalization by controlling for the levels of expected own and substitute fuel prices in the period prior to construction. In liberalized markets, higher fuel prices are expected to shift the balance towards more efficient generation technologies.

State level models:

Our basic, state-level model for capacity additions of each technology type is:

$$
\begin{aligned}
A_{i, t}^{k}= & \beta_{0}^{k}+\left(\beta_{1}^{k}+\beta_{3}^{k} \operatorname{PLIB}_{i, t}\right) \frac{1}{3} \sum_{j=L}^{L+3} \operatorname{Pcoal}_{i, t-j}+\left(\beta_{2}^{k}+\beta_{4}^{k} \operatorname{PLIB}_{i, t}\right) \frac{1}{3} \sum_{j=L}^{L+3} \operatorname{Pgas}_{i, t-j} \\
& +\gamma^{k} P L I B_{i, t}+\sum_{j=1}^{L+3} \lambda_{j}^{k} \sum_{k=1}^{K} A_{i, t-j}^{k}+\sum_{j=1}^{L+3} \rho_{j}^{k} \sum_{k=1}^{K} R_{i, t-j}^{k}+\varrho^{k} \frac{1}{3} \sum_{j=L}^{L+3} \tilde{Y}_{i, t-j}+\zeta^{k} E_{i, t-j} \\
& +\mu_{i}^{k}+\theta^{k} t^{k}+\varepsilon_{i, t}^{k},
\end{aligned}
$$


given $\sum_{k=1}^{K} A_{i, t}^{k} \neq 0$ - state-year observations with no overall capacity addition are dropped ${ }^{6}$-and where:

- $A_{i, t}^{k}=\ln \left(1+a_{i, t}^{k}\right)$, where $a_{i, t}^{k}$ is the capacity addition of a given technology " $k$ " in state " $i$ ", in year " $t$ ". $K$ is the number of different technologies that might be invested in. We added $1 \mathrm{MW}$ capacity to each data point in order to avoid zero values before taking the natural $\log$.

- $L$ is the estimated time taken to build a power plant of technology $\mathrm{k}$, discussed below.

- Pcoal $_{i, t}$ is the natural log of the real price of coal delivered to the electricity sector.

- $\operatorname{Pgas}_{i, t}$ is the similar price of natural gas. These prices are averaged over a three-year period prior to the estimated time that the construction decision commences in order to filter out the effect of short-run shortages on price expectations.

- $P L I B_{i, t}$ denotes the wholesale market liberalization dummy. The variable is equal to one from 1997 for ISO-NE, PJM, and ERCOT members; from 1998 for CAISO; from 1999 for NYISO; from 2002 for MISO members; and from 2004 for SPP members. See below for definitions of ISO regions.

- $\sum_{j=1}^{L+3} \lambda_{j}^{k} \sum_{k=1}^{K} A_{i, t-j}^{k}$ measures the effect of lagged capacity additions across all technologies. This includes other plants in a state that were ready or already in construction.

- $\sum_{j=1}^{L+3} \rho_{j}^{k} \sum_{k=1}^{K} R_{i, t-j}^{k}$ similarly measures the effect of lagged retirements, and

- $\sum_{j=L}^{L+3} \tilde{Y}_{i, t-j}$ measures the lagged three-year average state GDP growth rate before the construction start.

- $E_{i, t}$ denotes a dummy for stricter than federal emission control laws for electricity generation.

- $\mu_{i}^{k}$ denotes state fixed effects, and

- $t^{k}$ denotes a time trend. For nuclear power plants we also include a structural break in the form of a dummy variable, taking the value of 1 before 1979 and 0 thereafter.

We also present robustness checks using the medium-term expected prices published by the EIA. As in the case of Equation (1), we use a three-year moving average of expected prices. Unfortunately, the EIA data are not on a state level, therefore reducing the variation in our dataset. As expected prices follow real prices very closely, we think that using (the three-year average of) current prices for each state would be the best indicator of prices in the future when making investment decisions.

$$
\begin{aligned}
A_{i, t}^{k}= & \beta_{0}^{k}+\left(\beta_{1}^{k}+\beta_{3}^{k} \text { PLIB }_{i, t}\right) \frac{1}{3} \sum_{j=L}^{L+3} \text { EPcoal }_{t-j}+\left(\beta_{2}^{k}+\beta_{4}^{k} \text { PLIB }_{i, t}\right) \frac{1}{3} \sum_{j=L}^{L+3} \text { EPgas }_{t-j} \\
& +\gamma^{k} P L I B_{i, t}+\sum_{j=1}^{L+3} \lambda_{j}^{k} \sum_{k=1}^{K} A_{i, t-j}^{k}+\sum_{j=1}^{L+3} \rho_{j}^{k} \sum_{k=1}^{K} R_{i, t-j}^{k}+\varrho^{k} \frac{1}{3} \sum_{j=L}^{L+3} \tilde{Y}_{i, t-j}+\zeta^{k} E_{i, t-j} \\
& +\mu_{i}^{k}+\theta^{k} t^{k}+\varepsilon_{i, t}^{k},
\end{aligned}
$$

6. Such observations imply a decision not to build at all rather than a choice between technologies. Results for the full panel without this restriction do not significantly deviate from the results of Table 1 . However the coefficient estimates are generally lower. 
where,

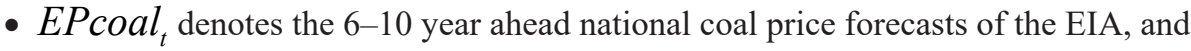

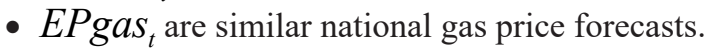

We use the EIA's (2017) estimates of lead times for new technologies entering service in the future. We add 1 year to their estimates $(+1)$, to account for the planning and decision-making phase. The adopted lead times are, therefore: $\mathrm{L}=4(+1)$ years for most coal technologies, $\mathrm{L}=3$ $(+1)$ years for gas combined cycles, $L=2(+1)$ years for combustion turbines, $L=6(+1)$ years for advanced nuclear plants, ${ }^{7}$ and $\mathrm{L}=3(+1)$ for wind turbines. The EIA's definition of lead-time is: "the time between the commencement of the licensing process, to the date of commercial operation" (EIA, 2004 p57). These lags also mean that there cannot be reverse causality from the amount of new technologies built to fuel prices on a state level.

We also use Lazard's (2016) construction times as a robustness check. These values are very similar to the EIA construction times, the main differences are the following: 1 year construction time for onshore wind, and 5 to 6 years for coal technologies. For NGFCC, gas peaking, and nuclear power plants the estimated construction times are identical or very similar to EIA estimates. We again add 1 year for planning.

Based on Craig and Savage's (2013) definitions, PLIB is a dummy for wholesale market restructuring or partly liberalized markets, which indicates that utilities in a state joined an ISO or an RTO in a given year. As retail market restructuring has few implications for technology choices at the generation level, we do not control for it. In total, 37 states fall into the category of having access to wholesale markets. Thus, we measure the effect of wholesale market choice on electricity investments both across states and before and after liberalization within states.

We also interact the natural log of fuel prices with the competitive wholesale market dummy to measure the difference in the impact of fuel prices on technology choice in liberalized and non-liberalized regimes. The relative marginal profit of a generator in a competitive wholesale market will be determined by the difference between the electricity market clearing price (that might be at or higher than the marginal cost of the last generating unit) and the marginal cost of generation (which will be mainly driven by fuel costs in the case of fossil fuel generation). As wholesale prices are not available for each state and year, and a state might belong to different electricity trading hubs, we assume that natural gas prices are the key drivers of wholesale electricity prices (DOE, 2017). Technological advances will also lead to changes in the preferred technologies. Biased technological change is allowed for by the time trend.

A key driver of investments (and capacity utilization) besides prices and market structure is long-term electricity demand development. Power plants are built when additional demand is present, a sufficient number of plants are retired, or market incentives are present for the new capacity even without additional demand. However, as we noted, already in the 1990s, parts of the U.S. market had overcapacity and thus underutilization (Borenstein and Bushnell, 2015). To measure the long-term development in power generation capacity and the lock-in nature of construction (and through it changes in supply), we control for lagged capacity additions across all technologies. This includes other plants in a state that were ready or already in construction. We also control for lagged retirements, and for the lagged three-year average state GDP growth rate.

7. The median construction time without the planning and authorization phase of all reactors in the U.S. is seven years (Csereklyei et al., 2016). Recent examples, such as Vogtle, call into question the realism of the official six-year building-time forecast. 
We use state fixed effects, $\mu_{i}$, to control for unobserved state specific characteristics including industrial structure, environmental laws, the policy environment, availability of financial credit, and consumer laws of the state. $t^{k}$ is a national time effect, controlling for factors such as technology shocks and changes in federal environmental regulation. We included a structural break for nuclear power construction starts to account for the impact of the TMI accident in 1979, which would have affected nuclear investment coming online after 1986.

ISO/RTO level models:

Construction decisions by power producers in a given state might be not only influenced by what is happening in that particular state, but also by changes in nearby states whose utilities belong to the same ISO/RTO. These centrally organized markets combine all day-ahead bids from the region into a single supply curve to determine the market clearing price for the ISO/RTO based on regional demand (DOE, 2017). Additionally, nearly all ISO's apply some scarcity pricing, and some markets also operate ancillary service markets (DOE, 2017). To control for the effect of capacity additions and retirements within an ISO/RTO, in addition to estimating Equations (1) and (2) using state level data, we present robustness checks with a restructured dataset, consisting of combined capacity additions and retirements of ISO/RTO markets on the one hand, and data from states without competitive wholesale markets on the other hand.

As a power producer from a certain state may belong to different ISO/RTO regions and it was not possible to select what part of the capacity in a state belongs to which ISO/ RTO, we assigned the additions of a state in some cases to more than one RTO. The cumulative additions of our regions are thus higher than the actual U.S. capacity additions of the constituent states.

We used the following ISO/RTO memberships:

- ISO-NE serves six New England states: Connecticut, Maine, Massachusetts, New Hampshire, Rhode Island, and Vermont. The ISO was formed in 1996 and became operational in 1997.

- PJM serves thirteen states: Delaware, Illinois, Indiana, Kentucky, Maryland, Michigan, New Jersey, North Carolina, Ohio, Pennsylvania, Tennessee, Virginia, and West Virginia. The ISO became fully functioning in 1996.

- MISO serves fifteen states: Arkansas, Illinois, Indiana, Iowa, Kentucky, Louisiana, Michigan, Minnesota, Mississippi, Missouri, Montana, North Dakota, South Dakota, Texas, and Wisconsin. MISO organized as an ISO in December 2001. Therefore, the first year we list it is 2002. It began market operations in 2005.

- SPP serves fourteen states: Arkansas, Iowa, Kansas, Louisiana, Minnesota, Missouri, Montana, Nebraska, New Mexico, North Dakota, Oklahoma, South Dakota, Texas, and Wyoming. SPP became an RTO in 2004, and operational in 2007.

- NYISO serves New York. The ISO formed in 1998 and started operations in 1999.

- CAISO serves California (and some balancing areas). It was founded in 1998 and became fully functioning in 2008.

- ERCOT covers the majority of Texas. The ISO was formed in 1996.

- As a result, our dataset contains 18 cross-sectional units, including the 7 ISO/RTO regions and 11 states without utilities participating in competitive wholesale markets. These states are: Alabama, Arizona, Colorado, Florida, Georgia, Idaho, Nevada, Oregon, South Carolina, Utah, and Washington. 
To estimate Equations (1) and (2) for the restructured dataset, we sum GDP data for the ISO/RTO regions, ${ }^{8}$ and for Equation (1) we average natural gas and coal prices for each region. The results are presented in Tables 3 and 4.

\section{B. Data}

We constructed a state-level panel dataset for the period 1970 to 2014. Additions to specific generating technologies were sourced from EIA form 860 for 2014. The EIA 860 (3.1 Generator) form includes currently operating and retired generating units in the United States by state, fuel, technology, and subtechnology, giving the date of first operation and retirement (EIA, 2016a). By using the 26 distinct technology categories defined by the EIA and assigning capacity (measured in MW nameplate capacity) to the year of first operation, we are able to construct a capacity additions database for all states between 1891 and 2014. The EIA data encompass utility and IPP investments in electricity generation, but not residential and industry-own generation, and, therefore, certain energy technologies, such as solar photovoltaic capacity might be underrepresented. Due to the availability of price and income data, however, we only use data from 1970 to $2014 .{ }^{9}$

We only estimate regressions for natural gas-fired combined cycle plants (NGFCC), natural gas-fired combustion turbines (NGFCT), conventional steam coal fluidized bed generator (CSC_FB), conventional steam coal pulverized coal technology (CSC_PV), subcritical and supercritical coal plants (CSC_SUB, CSC_SUP), nuclear reactors (NUC), and onshore wind turbines (OWT). Several highly efficient technologies did not have enough observations to estimate a regression. For example, there are only two observations on coal integrated gasification combined cycle technologies.

Price data, including the nominal values for coal and natural gas price in the electric power sector were sourced from the EIA's (2014) State Energy Data System (SEDS). We used the 2009 U.S. BEA (seasonally adjusted) GDP implicit price deflator to convert the values to 2009 dollars. The EIA (2014) reports that some of the energy prices for given states and years have been estimated, based on a number of assumptions, such as the prices in neighboring states, regional and national prices, or the growth rate of prices in adjacent regions. A detailed description of the methodology is found in the EIA (2014) technical notes.

As the SEDS dataset was still missing some prices, we have taken the same approach as the EIA (2014) and have estimated missing state-years using the average of the neighboring states' prices where original SEDS data were available. Averaged values were not used to generate further averages, except for Maine. As the only direct neighbor of Maine is New Hampshire, we had to use the data originally generated for New Hampshire. Due to the lack of substantial electricity generation in Washington D.C. and the lack of prices for Hawaii and Alaska (where estimation based on neighboring states with land borders was not possible), we have excluded these 2 states and Washington D.C. from the dataset.

8. Data for PJM starts in 1973.

9. The EIA identifies 6 sub-technologies within the conventional steam coal (CSC) category. These refer to the steam cycle (subcritical, supercritical, and ultra-supercritical) and to specific (efficient and less efficient) technologies such as stoker technology (oldest), pulverized coal (one of the most widespread coal technologies today), and fluidized bed (both highly efficient and environmentally friendly) technologies. As the EIA 860 dataset's categorization of subtechnologies is not mutually exclusive (sums up to more than the total capacity additions in the CSC category), we decided not to further break down the sample by multiplying steam cycle categories with these categories. Also, this would have further reduced our observation numbers for each category. 
Short- and mid-term gas and coal price forecasts (for the electricity generation sector) are taken from the EIA. We collected the base case scenario price forecasts from the EIAAnnual Energy Outlooks between 1979-2014 (EIA, various years). These were deflated with the GDP implicit price deflator to 2009 dollars.

The state GDP series were constructed using data from the Bureau of Economic Analysis (BEA), and the BEA GDP implicit price deflator. From 1997 to 2014 we used the BEA NAICS real GDP series in chained 2009 dollars. ${ }^{10}$ The BEA warns of a discontinuity in the GDP-by-state time series at 1997, where the Bureau shifted from SIC industry definitions to NAICS industry definitions. While the NAICS definition is consistent with the U.S. gross domestic product, the SIC definition measures the U.S. gross domestic income. Therefore, we used the growth rate of the SIC GDP series after it was converted to real (2009) dollars and extrapolated the NAICS series backward with these growth rates.

\section{RESULTS}

\section{A. State level models}

We present the estimates of Equation (1) in Table 1. The estimates using forecasted midterm gas and coal prices of the EIA, as specified in Equation (2), are found in Table 2.

\section{Estimates with actual fuel prices}

The coefficient of the liberalized wholesale markets dummy is positive for natural gas combined cycle plants and significant at the $10 \%$ level, while it is negative for most coal technologies and significant at the $1 \%$ or $5 \%$ level. The coefficient is negative for both sub- and supercritical coal-fired generators, though somewhat less negative for supercritical coal plants. We do not find any effect of wholesale market liberalization on fluidized bed generation additions. As most coal generators built after 2000 were supercritical, our results indicate that high efficiency coal generators (including fluidized bed plants) are less negatively influenced by market liberalization. The introduction of liberalized wholesale markets also resulted in increased natural gas combined cycle investment. This finding might be attributable to the investor expectations that natural gas-fired generators would provide the best return on investment in the future.

The own fuel price elasticity of coal is usually not significant in rate-of-return markets, indicating that operating expenses matter little when there is a guaranteed return on investment. The own price elasticity of natural gas combined cycle plants is negative and significant at the $10 \%$ level in rate-of-return markets. In states with liberalized wholesale markets, the coefficient is higher, at -2.03 and significant at the $1 \%$ level, indicating a very elastic response of investment to gas price changes.

The own fuel price elasticity of natural gas-fired turbines is not statistically significant under liberalized wholesale markets. Investment in natural gas-fired peak loaders seems to react negatively to increases in coal price under rate-of-return regulations. As coal generators are mostly used for baseload, and natural gas turbines for peak load, we think that this relationship is a coincidence rather than a structural relationship. Peak loaders, whatever their fuel, are used very flexibly and have to recover their investments in periods of high demand and, therefore, very high electricity

10. According to the BEA definition, GDP by state is derived as the sum of the GDP originating in all the industries in a state (BEA, 2016). 
Table 1: State-level estimates using actual fuel prices and EIA lead times (plus one year of planning time), see Equation (1).

\begin{tabular}{|c|c|c|c|c|c|c|c|c|}
\hline State level & $\begin{array}{l}(1) \\
\text { csc_fb }\end{array}$ & $\begin{array}{c}(2) \\
\text { csc_pc }\end{array}$ & $\begin{array}{c}(3) \\
\text { csc_sub }\end{array}$ & $\begin{array}{c}\text { (4) } \\
\text { csc_sup }\end{array}$ & $\begin{array}{c}(5) \\
\text { ngfcc }\end{array}$ & $\begin{array}{c}(6) \\
\text { ngfct }\end{array}$ & $\begin{array}{l}(7) \\
\text { nuc }\end{array}$ & $\begin{array}{l}(8) \\
\text { owt }\end{array}$ \\
\hline $\begin{array}{l}\text { Liberalized wholesale } \\
\text { markets (PLIB) }\end{array}$ & $\begin{array}{l}-0.33 \\
(0.34)\end{array}$ & $\begin{array}{c}-3.16^{* * *} \\
(0.88)\end{array}$ & $\begin{array}{c}-2.27 * * * \\
(0.58)\end{array}$ & $\begin{array}{c}-1.47 * * \\
(0.67)\end{array}$ & $\begin{array}{l}2.41^{*} \\
(1.24)\end{array}$ & $\begin{array}{c}0.24 \\
(1.06)\end{array}$ & $\begin{array}{c}0.42 \\
(0.48)\end{array}$ & $\begin{array}{c}0.52 \\
(1.10)\end{array}$ \\
\hline $\begin{array}{l}\text { Lagged ln av. coal } \\
\text { price }\end{array}$ & $\begin{array}{c}0.10 \\
(0.18)\end{array}$ & $\begin{array}{l}-0.53 \\
(0.98)\end{array}$ & $\begin{array}{c}0.07 \\
(0.77)\end{array}$ & $\begin{array}{c}-1.24^{*} \\
(0.73)\end{array}$ & $\begin{array}{c}0.92 \\
(0.85)\end{array}$ & $\begin{array}{l}-1.19^{*} \\
(0.68)\end{array}$ & $\begin{array}{l}-0.34 \\
(1.00)\end{array}$ & $\begin{array}{c}0.47 \\
(0.40)\end{array}$ \\
\hline Lagged ln av. gas price & $\begin{array}{c}0.33 \\
(0.21)\end{array}$ & $\begin{array}{l}-0.53 \\
(0.48)\end{array}$ & $\begin{array}{l}-0.19 \\
(0.52)\end{array}$ & $\begin{array}{c}0.22 \\
(0.22)\end{array}$ & $\begin{array}{c}-0.75^{*} \\
(0.44)\end{array}$ & $\begin{array}{c}0.14 \\
(0.39)\end{array}$ & $\begin{array}{c}0.83 \\
(0.61)\end{array}$ & $\begin{array}{l}-0.12 \\
(0.40)\end{array}$ \\
\hline $\begin{array}{l}\text { Lagged ln av. coal } \\
\text { price*PLIB }\end{array}$ & $\begin{array}{c}0.04 \\
(0.30)\end{array}$ & $\begin{array}{c}0.41 \\
(0.91)\end{array}$ & $\begin{array}{c}0.90 \\
(0.87)\end{array}$ & $\begin{array}{l}0.19 \\
(0.55)\end{array}$ & $\begin{array}{l}-1.29 \\
(1.00)\end{array}$ & $\begin{array}{c}0.95 \\
(0.72)\end{array}$ & $\begin{array}{c}0.14 \\
(0.56)\end{array}$ & $\begin{array}{c}-3.11 * * * \\
(0.69)\end{array}$ \\
\hline $\begin{array}{l}\text { Lagged ln av. gas } \\
\text { price*PLIB }\end{array}$ & $\begin{array}{c}0.04 \\
(0.22)\end{array}$ & $\begin{array}{l}2.12 * * * \\
(0.56)\end{array}$ & $\begin{array}{c}1.17 * * * \\
(0.43)\end{array}$ & $\begin{array}{l}0.88^{* *} \\
(0.39)\end{array}$ & $\begin{array}{l}-1.28 \\
(0.84)\end{array}$ & $\begin{array}{l}-1.05 \\
(0.72)\end{array}$ & $\begin{array}{l}-0.38 \\
(0.49)\end{array}$ & $\begin{array}{l}1.19 \\
(0.76)\end{array}$ \\
\hline $\begin{array}{l}\text { Lagged ln av. GDP } \\
\text { growth }\end{array}$ & $\begin{array}{l}1.99 \\
(2.08)\end{array}$ & $\begin{array}{c}0.03 \\
(5.31)\end{array}$ & $\begin{array}{l}-0.63 \\
(4.74)\end{array}$ & $\begin{array}{c}1.92 \\
(1.80)\end{array}$ & $\begin{array}{c}25.27 * * * \\
(4.52)\end{array}$ & $\begin{array}{c}16.92 * * * \\
(4.54)\end{array}$ & $\begin{array}{l}-2.81 \\
(3.49)\end{array}$ & $\begin{array}{l}7.73^{* *} \\
(3.72)\end{array}$ \\
\hline $\begin{array}{l}\text { Lagged Environmental } \\
\text { Laws }\end{array}$ & $\begin{array}{l}-0.16 \\
(0.12)\end{array}$ & $\begin{array}{c}0.86 \\
(0.54)\end{array}$ & $\begin{array}{c}0.76 \\
(0.49)\end{array}$ & $\begin{array}{c}0.23 \\
(0.22)\end{array}$ & $\begin{array}{c}-0.96^{* *} \\
(0.41)\end{array}$ & $\begin{array}{l}-0.19 \\
(0.95)\end{array}$ & $\begin{array}{c}0.20 \\
(0.21)\end{array}$ & $\begin{array}{c}0.63 \\
(1.18)\end{array}$ \\
\hline Structural Break & & & & & & & $\begin{array}{c}0.73 \\
(0.76)\end{array}$ & \\
\hline Time trend & $\begin{array}{c}0.00 \\
(0.00)\end{array}$ & $\begin{array}{c}-0.10 * * * \\
(0.02)\end{array}$ & $\begin{array}{c}-0.09 * * * \\
(0.02)\end{array}$ & $\begin{array}{c}-0.04 * * \\
(0.02)\end{array}$ & $\begin{array}{l}0.08 * * * \\
(0.02)\end{array}$ & $\begin{array}{l}0.07 * * * \\
(0.02)\end{array}$ & $\begin{array}{l}-0.02 \\
(0.03)\end{array}$ & $\begin{array}{l}0.04 * * \\
(0.01)\end{array}$ \\
\hline \multicolumn{9}{|c|}{ Liberalized Wholesale Market Coefficients } \\
\hline Lagged ln av. gas price & 0.38 & $1.59 * *$ & $0.99 *$ & $1.10^{* *}$ & $-2.03 * * *$ & -0.91 & 0.46 & 1.07 \\
\hline $\begin{array}{l}\text { Lagged ln av. coal } \\
\text { price }\end{array}$ & 0.13 & -0.12 & 0.97 & -1.04 & -0.36 & -0.24 & -0.20 & $-2.65 * * *$ \\
\hline $\begin{array}{l}\text { Lagged ln capacity } \\
\text { additions }\end{array}$ & Yes & Yes & Yes & Yes & Yes & Yes & Yes & Yes \\
\hline $\begin{array}{l}\text { Lagged ln capacity } \\
\text { retirements }\end{array}$ & Yes & Yes & Yes & Yes & Yes & Yes & Yes & Yes \\
\hline $\begin{array}{l}\text { Planning \& lead times/ } \\
\text { (\#Lags) }\end{array}$ & 5 & 5 & 5 & 5 & 4 & 3 & 7 & 4 \\
\hline $\mathrm{N}$ & 780 & 780 & 780 & 780 & 853 & 935 & 658 & 853 \\
\hline adj. Rsq. & 0.013 & 0.203 & 0.174 & 0.074 & 0.181 & 0.106 & 0.050 & 0.372 \\
\hline
\end{tabular}

Notes: Standard errors in parentheses. Lags of capacity additions and retirements are included in the regressions but now shown in the Table. p-values are reported as follows: $* p<0.10, * * p<0.05,{ }^{* * *} p<0.01$. Constants are not reported.

prices. This is in line with the finding of Joskow (2008), who notes insufficient investment in peakload technologies under liberalization.

The cross-price elasticities for coal technologies with respect to the price of natural gas in liberalized wholesale markets show a clear investment substitution towards coal-fired baseload generation when natural gas prices increase. The combined coefficients in Table 1 vary between 1.10 for supercritical to 1.59 for general steam coal technologies and are significant at the $5 \%$ level.

The three- to four-fold increase in natural gas prices in the early to mid 2000 s resulted in relatively higher income for non-natural gas-fired baseload generators. ${ }^{11}$ While new coal additions during the 2000s were negligible, the years 2010-2013 have seen some minor coal investments come online, mostly as a result of high natural gas prices in the mid 2000s, and the expectation of continuing high prices (see Figure 5). These generating units entered service around 2010, but their

11. As a result of the gas price hikes in the mid 2000s, operators were running natural gas-fired power plants only when all available coal, nuclear or renewable capacity had been exploited, therefore, further decreasing the capacity utilization and the profitability of natural gas baseload generation. 
Table 2: State-level estimates using expected fuel prices and EIA lead times (plus one year planning time), see Equation (2).

\begin{tabular}{|c|c|c|c|c|c|c|c|c|}
\hline State level & $\begin{array}{c}(1) \\
\text { csc_fb }\end{array}$ & $\begin{array}{l}(2) \\
\text { csc_pc }\end{array}$ & $\begin{array}{c}(3) \\
\text { csc_sub }\end{array}$ & $\begin{array}{c}\text { (4) } \\
\text { csc_sup }\end{array}$ & $\begin{array}{c}(5) \\
\text { ngfcc }\end{array}$ & $\begin{array}{c}(6) \\
\text { ngfct }\end{array}$ & $\begin{array}{l}(7) \\
\text { nuc }\end{array}$ & $\begin{array}{l}(8) \\
\text { owt }\end{array}$ \\
\hline $\begin{array}{l}\text { Liberalized wholesale } \\
\text { markets (PLIB) }\end{array}$ & $\begin{array}{c}0.59 \\
(0.66)\end{array}$ & $\begin{array}{l}-2.37 * * \\
(1.03)\end{array}$ & $\begin{array}{l}-0.61 \\
(0.90)\end{array}$ & $\begin{array}{c}-0.99 * \\
(0.56)\end{array}$ & $\begin{array}{c}2.23 \\
(1.74)\end{array}$ & $\begin{array}{l}-2.93 \\
(1.82)\end{array}$ & $\begin{array}{l}-0.63 \\
(0.98)\end{array}$ & $\begin{array}{l}-1.28 \\
(1.22)\end{array}$ \\
\hline $\begin{array}{l}\text { Lagged ln av. expected } \\
\text { coal price }\end{array}$ & $\begin{array}{l}0.70^{*} \\
(0.36)\end{array}$ & $\begin{array}{l}-1.16^{*} \\
(0.67)\end{array}$ & $\begin{array}{l}-0.50 \\
(0.60)\end{array}$ & $\begin{array}{l}-0.16 \\
(0.20)\end{array}$ & $\begin{array}{c}0.17 \\
(0.98)\end{array}$ & $\begin{array}{c}-1.86^{* * *} \\
(0.68)\end{array}$ & $\begin{array}{l}-1.48 \\
(1.42)\end{array}$ & $\begin{array}{l}-2.11^{*} \\
(1.05)\end{array}$ \\
\hline $\begin{array}{l}\text { Lagged ln av. expected } \\
\text { gas price }\end{array}$ & $\begin{array}{c}0.21 \\
(0.30)\end{array}$ & $\begin{array}{c}0.53 \\
(0.40)\end{array}$ & $\begin{array}{l}0.76^{*} \\
(0.43)\end{array}$ & $\begin{array}{c}0.18 \\
(0.15)\end{array}$ & $\begin{array}{c}-1.46^{* *} \\
(0.65)\end{array}$ & $\begin{array}{c}-1.99 * * * \\
(0.50)\end{array}$ & $\begin{array}{c}0.51 \\
(0.49)\end{array}$ & $\begin{array}{l}1.17 * \\
(0.63)\end{array}$ \\
\hline $\begin{array}{l}\text { Lagged ln av. expected } \\
\text { coal price*PLIB }\end{array}$ & $\begin{array}{c}-1.49^{*} \\
(0.76)\end{array}$ & $\begin{array}{l}-1.08 \\
(0.73)\end{array}$ & $\begin{array}{c}-1.61^{*} \\
(0.93)\end{array}$ & $\begin{array}{c}-0.76^{*} \\
(0.44)\end{array}$ & $\begin{array}{c}0.22 \\
(1.56)\end{array}$ & $\begin{array}{l}-0.06 \\
(1.35)\end{array}$ & $\begin{array}{l}-0.19 \\
(0.25)\end{array}$ & $\begin{array}{l}-0.15 \\
(1.32)\end{array}$ \\
\hline $\begin{array}{l}\text { Lagged } \ln \text { av. expected } \\
\text { gas price*PLIB }\end{array}$ & $\begin{array}{c}0.05 \\
(0.43)\end{array}$ & $\begin{array}{c}2.09^{* * *} \\
(0.76)\end{array}$ & $\begin{array}{l}0.93 * \\
(0.53)\end{array}$ & $\begin{array}{l}1.02 * * \\
(0.47)\end{array}$ & $\begin{array}{l}-1.76 \\
(1.33)\end{array}$ & $\begin{array}{c}1.36 \\
(1.44)\end{array}$ & $\begin{array}{c}0.44 \\
(0.53)\end{array}$ & $\begin{array}{c}1.10 \\
(1.15)\end{array}$ \\
\hline $\begin{array}{l}\text { Lagged ln av. GDP } \\
\text { growth }\end{array}$ & $\begin{array}{c}1.23 \\
(2.36)\end{array}$ & $\begin{array}{c}1.46 \\
(3.63)\end{array}$ & $\begin{array}{l}-0.47 \\
(3.47)\end{array}$ & $\begin{array}{l}4.11^{* *} \\
(2.01)\end{array}$ & $\begin{array}{c}23.73 * * * \\
(5.13)\end{array}$ & $\begin{array}{c}13.97 * * * \\
(4.37)\end{array}$ & $\begin{array}{l}-0.03 \\
(5.30)\end{array}$ & $\begin{array}{c}13.11 * * * \\
(4.12)\end{array}$ \\
\hline $\begin{array}{l}\text { Lagged Environmental } \\
\text { Laws }\end{array}$ & $\begin{array}{l}-0.13 \\
(0.14)\end{array}$ & $\begin{array}{l}-0.03 \\
(0.25)\end{array}$ & $\begin{array}{c}0.16 \\
(0.23)\end{array}$ & $\begin{array}{l}-0.28 \\
(0.18)\end{array}$ & $\begin{array}{l}-0.24 \\
(0.40)\end{array}$ & $\begin{array}{c}0.86 \\
(0.78)\end{array}$ & $\begin{array}{c}0.26 \\
(0.18)\end{array}$ & $\begin{array}{c}0.21 \\
(1.05)\end{array}$ \\
\hline Time trend & $\begin{array}{c}0.01 \\
(0.01)\end{array}$ & $\begin{array}{c}-0.06 * * * \\
(0.02)\end{array}$ & $\begin{array}{c}-0.04 * * \\
(0.02)\end{array}$ & $\begin{array}{l}-0.01 \\
(0.01)\end{array}$ & $\begin{array}{c}0.01 \\
(0.03)\end{array}$ & $\begin{array}{c}-0.05 * * \\
(0.02)\end{array}$ & $\begin{array}{l}-0.05 \\
(0.04)\end{array}$ & $\begin{array}{c}0.01 \\
(0.02)\end{array}$ \\
\hline \multicolumn{9}{|c|}{ Liberalized Wholesale Market Coefficients } \\
\hline $\begin{array}{l}\text { Lagged ln av. expected } \\
\text { gas price }\end{array}$ & 0.26 & $2.62 * * *$ & $1.69 * * *$ & $1.21 * *$ & $-3.22 * * *$ & -0.63 & 0.96 & $2.28 * *$ \\
\hline $\begin{array}{l}\text { Lagged ln av. expected } \\
\text { coal price }\end{array}$ & -0.80 & $-2.24 * *$ & $-2.11 * * *$ & $-0.92 *$ & 0.40 & -1.93 & -1.66 & $-2.26 * *$ \\
\hline $\begin{array}{l}\text { Lagged ln capacity } \\
\text { additions }\end{array}$ & Yes & Yes & Yes & Yes & Yes & Yes & Yes & Yes \\
\hline $\begin{array}{l}\text { Lagged ln capacity } \\
\text { retirements }\end{array}$ & Yes & Yes & Yes & Yes & Yes & Yes & Yes & Yes \\
\hline $\begin{array}{l}\text { Planning \& lead times/ } \\
\text { (\#Lags) }\end{array}$ & 5 & 5 & 5 & 5 & 4 & 3 & 7 & 4 \\
\hline $\mathrm{N}$ & 646 & 646 & 646 & 646 & 705 & 773 & 541 & 705 \\
\hline adj. Rsq. & 0.021 & 0.053 & 0.064 & 0.044 & 0.182 & 0.152 & 0.049 & 0.312 \\
\hline
\end{tabular}

Notes: Standard errors in parentheses. Lags of capacity additions and retirements are included in the regressions but now shown in the Table. $p$-values are reported as follows: $* p<0.10,{ }^{* *} p<0.05,{ }^{* * *} p<0.01$. Constants are not reported.

construction started during peak natural gas (and, therefore, peak electricity) prices. About $70 \%$ of this new capacity $(10.2 \mathrm{GW})$ consisted of supercritical plants. Figure 6 shows the development of natural gas and coal-fired generation as a percentage of the total annual capacity addition.

We also examine the response of investment in wind generation and nuclear plants to the above factors. Wind resources are concentrated in the central parts of the U.S., which is overwhelmingly covered by ERCOT and SPP. At the same time, the regulated southeastern part of the U.S. is very scarce in wind resources. The coal cross price elasticity for wind turbines is negative under liberalized wholesale markets. However, wind and coal are not direct substitutes, as wind cannot provide base-load generation in the absence of large-scale storage. The DOE (2017) also notes that apart from the technology-driven decline in cost, state and renewable portfolio standards, production tax credits, and state air quality and environmental policies were the key drivers of wind deployment. Especially in wind-rich areas, generous investment financing of onshore wind turbines contributed to the success of the technology. These policies are captured by the positive national time trend. There do not seem to be enough observations for nuclear power plants to obtain significant results in state level regressions.

The coefficient on lagged state average GDP growth is positive and significant for natural gas technologies and wind turbines. Stricter than federal emissions laws were found to have a 
Figure 6: All natural gas and coal-fired new capacity in the U.S. as a \% of the total 1970-2014.

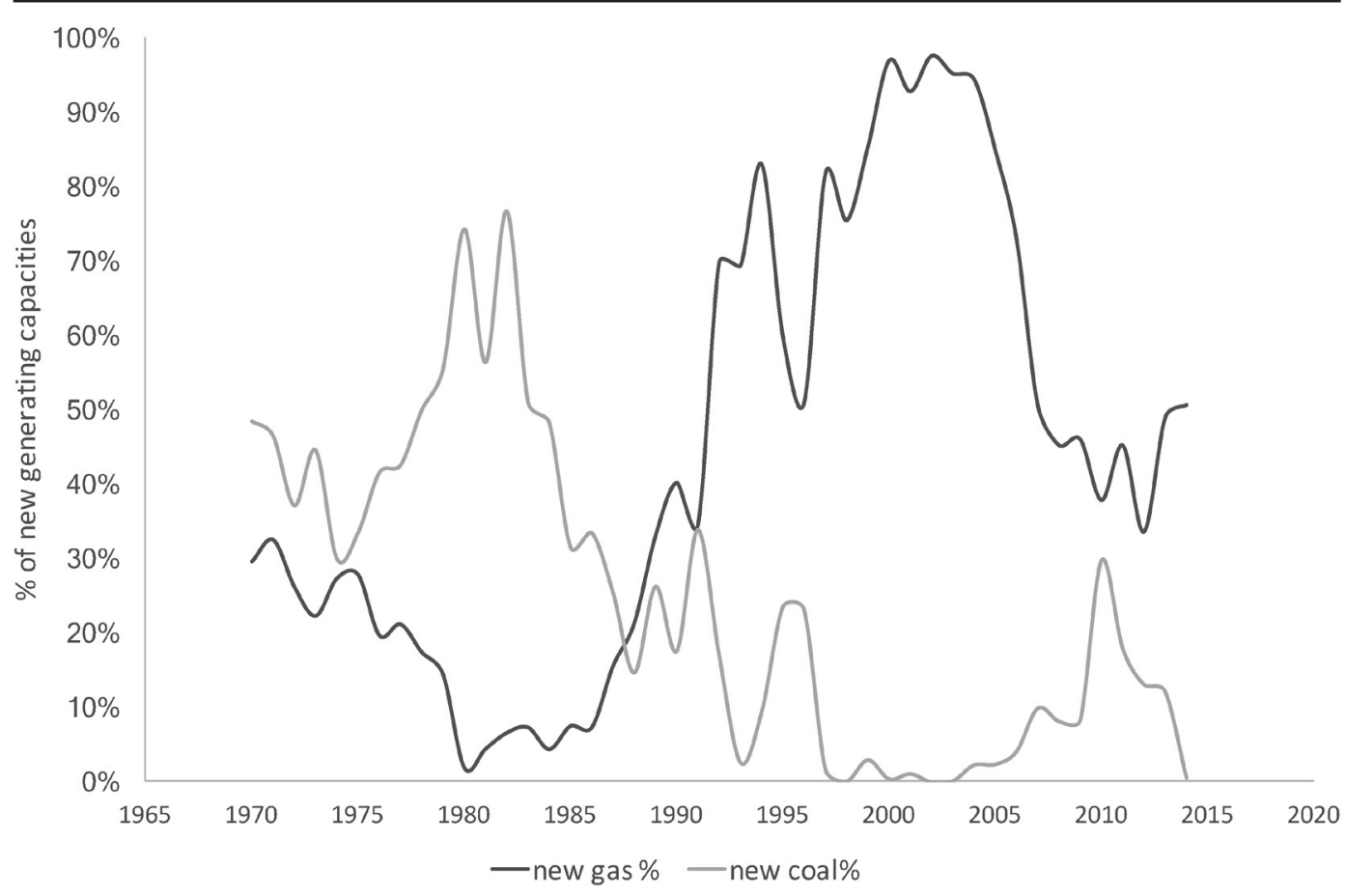

Source: Form 860-Y2014 (EIA, 2016a).

slight negative effect on natural gas-fired combined cycle generators. This is surprising, as natural gas-fired combined cycle plants have much lower emissions than baseload coal-fired power plants. However, these laws were enacted only recently, and so they impact only a small fraction of the sample. It would be worthwhile to conduct this regression in the future with more observations.

The time trends are significantly negative for all coal technologies, except for fluidized bed generators. These technology specific time trends capture regulation other than the introduction of liberalized wholesale markets. Even before the market restructuring process began in the late 1990s, the EPA pursued more stringent environmental standards, such as the New Source Amendment to the Clean Air Act, 1977. A number of regulations also impacted on the economics of coal plants after wholesale restructuring, the most important of which were the MATS and Coal Combustion Residuals Rule. These policies resulted in the declining profitability of coal generators and in several coal plant closures. Under liberalized wholesale markets, however, the economics of coal-fired power plants changed again. As natural gas prices plummeted in the late 2000s, many coal plants were not any more operating in a base-load capacity but often provided back-up capacity (DOE, 2017)

The time trend is positive and significant for natural gas technologies as well as for onshore wind turbines. From a policy perspective the most likely driver of the gas trend is the Powerplant and Industrial Fuel Use Act of 1978 (FUA), which limited the building of gas or oil-fired power stations, until its repeal in 1987.

\section{Estimates with EIA expected fuel prices}

Table 2 presents our results using the projected mid-term prices of the EIA. We find that in liberalized wholesale markets the own price elasticity of coal is negative and significant for all steam 
coal technologies at the 1 to $10 \%$ level, except for fluidized bed generators. The magnitude of the coefficient varies between -0.9 and -2.2 .

In rate-of-return markets, the own price elasticity of natural gas combined cycle plants is -1.46 and significant at the $5 \%$ level. Under liberalized wholesale markets the coefficient is more elastic at -3.22 and significant at the $1 \%$ level. This coefficient is notably higher than the coefficient in Table 1. We also find a negative own price elasticity under rate-of-return markets for natural gasfired combustion turbines. As in Table 1, we report a negative cross price elasticity with respect to coal prices.

We find positive and significant cross price elasticities for coal investments with respect to forecasted natural gas prices in liberalized markets. These elasticities are much higher than in Table 1 , indicating up to a $2.6 \%$ increase in coal investment as a result of a $1 \%$ increase in natural gas price expectations. With respect to wind turbines, we find a positive cross-price elasticity of expected natural gas prices both in regulated and restructured markets. This finding is different from Table 1 . As renewable sources have zero marginal cost, their marginal profit is expected to be considerably higher with higher natural gas prices in liberalized wholesale markets.

A condition of baseload natural gas-fired generation profitability is relatively low natural gas prices, as these prices tend to drive electricity prices and thus cost-profit margins and capacity utilization. Due to the shale gas boom, an unforeseen technological development, natural gas prices dropped close to the level of coal prices after 2010 (Figure 2), and the EIA (2016e) currently expects them to increase only moderately. However, significant future increases in price expectations of natural gas might see generation investment shift into more profitable facilities under competitive wholesale market conditions. Such substitution is however not observed in regulated markets, where the regulator sets the return.

The coefficient on lagged state average GDP growth is positive and significant for natural gas technologies, and wind turbines as well as supercritical coal generators. Stricter than federal emissions laws were not found to have significant effects in regressions where price expectations are accounted for. As a robustness check, we also use Lazard's estimated construction times, where these are different from the EIA's, adding 1 year for planning. The results for Equation (2) are presented in the Appendix, Table A1.

\section{B. ISO/RTO level models}

We present the results of our ISO/RTO level models in Table 3, for Equation (1), and in Table 4, for Equation (2).

\section{Estimates with actual fuel prices}

We find the effect of wholesale restructuring still significantly negative on coal-fired baseload power and positive but not significant for natural gas-fired baseload generators (Table 3 ). The own price elasticity of coal generators is significantly negative at the $10 \%$ level for supercritical generators under rate-of-return regulations.

In contrast to Table 1, most coal technologies display a negative and significant own price elasticity under liberalized wholesale markets. The cross-price elasticity of natural gas for coal generators is positive and significant in all cases. There are only minor differences in our findings using expected prices, most notably all estimated elasticities are higher, as is the case in the statelevel models. 
Table 3: ISO/RTO level estimates using actual fuel prices and EIA lead times (plus one year of planning time), see Equation (1).

\begin{tabular}{|c|c|c|c|c|c|c|c|c|}
\hline ISO/RTO level & $\begin{array}{c}(1) \\
\text { csc_fb }\end{array}$ & $\begin{array}{c}(2) \\
\text { csc_pc }\end{array}$ & $\begin{array}{c}\text { (3) } \\
\text { csc_sub }\end{array}$ & $\begin{array}{c}\text { (4) } \\
\text { csc_sup }\end{array}$ & $\begin{array}{c}(5) \\
\text { ngfcc }\end{array}$ & $\begin{array}{c}(6) \\
\text { ngfct }\end{array}$ & $\begin{array}{l}\text { (7) } \\
\text { nuc }\end{array}$ & $\begin{array}{l}\text { (8) } \\
\text { owt }\end{array}$ \\
\hline $\begin{array}{l}\text { Liberalized wholesale } \\
\text { markets (PLIB) }\end{array}$ & $\begin{array}{c}0.54 \\
(0.52)\end{array}$ & $\begin{array}{c}-3.99 * * \\
(1.86)\end{array}$ & $\begin{array}{l}-2.09 * \\
(1.02)\end{array}$ & $\begin{array}{c}-4.03 * * \\
(1.77)\end{array}$ & $\begin{array}{c}1.70 \\
(2.33)\end{array}$ & $\begin{array}{c}0.14 \\
(1.52)\end{array}$ & $\begin{array}{c}1.88 \\
(1.09)\end{array}$ & $\begin{array}{l}-0.03 \\
(1.83)\end{array}$ \\
\hline $\begin{array}{l}\text { Lagged ln av. coal } \\
\text { price }\end{array}$ & $\begin{array}{c}0.00 \\
(0.31)\end{array}$ & $\begin{array}{l}-0.60 \\
(1.36)\end{array}$ & $\begin{array}{c}0.55 \\
(0.98)\end{array}$ & $\begin{array}{l}-1.80^{*} \\
(0.97)\end{array}$ & $\begin{array}{c}0.84 \\
(1.04)\end{array}$ & $\begin{array}{l}-1.40 \\
(0.91)\end{array}$ & $\begin{array}{c}0.92 \\
(1.37)\end{array}$ & $\begin{array}{l}-0.23 \\
(0.56)\end{array}$ \\
\hline Lagged ln av. gas price & $\begin{array}{l}0.82 * * \\
(0.33)\end{array}$ & $\begin{array}{c}0.19 \\
(0.72)\end{array}$ & $\begin{array}{c}0.05 \\
(0.56)\end{array}$ & $\begin{array}{c}0.24 \\
(0.38)\end{array}$ & $\begin{array}{l}-0.71 \\
(0.54)\end{array}$ & $\begin{array}{c}0.38 \\
(0.41)\end{array}$ & $\begin{array}{l}2.01 * * \\
(0.76)\end{array}$ & $\begin{array}{c}0.05 \\
(0.62)\end{array}$ \\
\hline $\begin{array}{l}\text { Lagged } \ln \text { av. coal } \\
\text { price*PLIB }\end{array}$ & $\begin{array}{c}-1.61^{* *} \\
(0.65)\end{array}$ & $\begin{array}{l}-2.60 \\
(1.89)\end{array}$ & $\begin{array}{c}0.39 \\
(1.63)\end{array}$ & $\begin{array}{l}-2.24 * * * \\
\quad(0.50)\end{array}$ & $\begin{array}{l}-2.47^{*} \\
(1.19)\end{array}$ & $\begin{array}{c}0.01 \\
(0.76)\end{array}$ & $\begin{array}{c}2.17 \\
(1.43)\end{array}$ & $\begin{array}{l}-4.70 * * * \\
(0.96)\end{array}$ \\
\hline $\begin{array}{l}\text { Lagged ln av. gas } \\
\text { price*PLIB }\end{array}$ & $\begin{array}{c}0.40 \\
(0.48)\end{array}$ & $\begin{array}{c}4.14 * * * \\
(1.29)\end{array}$ & $\begin{array}{l}1.44 * * \\
(0.60)\end{array}$ & $\begin{array}{l}3.79 * * \\
(1.35)\end{array}$ & $\begin{array}{l}-0.70 \\
(1.53)\end{array}$ & $\begin{array}{c}0.32 \\
(0.79)\end{array}$ & $\begin{array}{c}-2.48 * * \\
(1.01)\end{array}$ & $\begin{array}{l}2.87^{*} \\
(1.64)\end{array}$ \\
\hline $\begin{array}{l}\text { Lagged ln av. GDP } \\
\text { growth }\end{array}$ & $\begin{array}{l}-0.18 \\
(2.99)\end{array}$ & $\begin{array}{l}-4.49 \\
(8.07)\end{array}$ & $\begin{array}{l}-3.29 \\
(6.90)\end{array}$ & $\begin{array}{c}0.20 \\
(3.69)\end{array}$ & $\begin{array}{l}36.11 * * * \\
(6.15)\end{array}$ & $\begin{array}{l}16.35^{* * *} \\
(5.45)\end{array}$ & $\begin{array}{l}-4.34 \\
(6.71)\end{array}$ & $\begin{array}{l}10.10 \\
(6.02)\end{array}$ \\
\hline $\begin{array}{l}\text { Lagged Environmental } \\
\text { Laws }\end{array}$ & $\begin{array}{c}0.00 \\
(0.20)\end{array}$ & $\begin{array}{c}1.14 \\
(0.92)\end{array}$ & $\begin{array}{l}1.19^{*} \\
(0.64)\end{array}$ & $\begin{array}{c}0.44 \\
(0.59)\end{array}$ & $\begin{array}{c}-1.77 * * * \\
(0.57)\end{array}$ & $\begin{array}{l}-0.55 \\
(0.85)\end{array}$ & $\begin{array}{l}0.59^{*} \\
(0.29)\end{array}$ & $\begin{array}{c}0.95 \\
(1.25)\end{array}$ \\
\hline Structural Break & & & & & & & $\begin{array}{l}2.39^{*} \\
(1.17)\end{array}$ & \\
\hline Time trend & $\begin{array}{c}0.02 \\
(0.01)\end{array}$ & $\begin{array}{c}-0.09 * * \\
(0.04)\end{array}$ & $\begin{array}{c}-0.07 * \\
(0.03)\end{array}$ & $\begin{array}{c}-0.04 * \\
(0.02)\end{array}$ & $\begin{array}{c}0.13 * * * \\
(0.03)\end{array}$ & $\begin{array}{c}0.07 * * * \\
(0.02)\end{array}$ & $\begin{array}{l}-0.00 \\
(0.03)\end{array}$ & $\begin{array}{c}0.05^{* *} \\
(0.02)\end{array}$ \\
\hline \multicolumn{9}{|c|}{ Liberalized wholesale Market Coefficients } \\
\hline $\begin{array}{l}\text { Lagged } \ln \text { av. gas price } \\
\text { Lagged } \ln \text { av. coal } \\
\text { price }\end{array}$ & $\begin{array}{c}1.22^{*} \\
-1.61 *\end{array}$ & $\begin{array}{l}4.32 * * \\
-3.19 *\end{array}$ & $\begin{array}{c}1.50^{*} \\
0.94\end{array}$ & $\begin{array}{c}4.03 * * \\
-4.05^{* * *}\end{array}$ & $\begin{array}{c}-1.41 \\
-1.63 * *\end{array}$ & $\begin{array}{c}0.70 \\
-1.39\end{array}$ & $\begin{array}{c}-0.47 \\
3.09\end{array}$ & $\begin{array}{c}2.92 * * \\
-4.94 * * *\end{array}$ \\
\hline $\begin{array}{l}\text { Lagged ln capacity } \\
\text { additions }\end{array}$ & Yes & Yes & Yes & Yes & Yes & Yes & Yes & Yes \\
\hline $\begin{array}{l}\text { Lagged ln capacity } \\
\text { retirements }\end{array}$ & Yes & Yes & Yes & Yes & Yes & Yes & Yes & Yes \\
\hline $\begin{array}{l}\text { Planning \& lead times/ } \\
\text { (\#Lags) }\end{array}$ & 5 & 5 & 5 & 5 & 4 & 3 & 7 & 4 \\
\hline $\begin{array}{l}\mathrm{N} \\
\text { adj. Rsq. }\end{array}$ & $\begin{array}{c}438 \\
0.034\end{array}$ & $\begin{array}{c}438 \\
0.251\end{array}$ & $\begin{array}{c}438 \\
0.223\end{array}$ & $\begin{array}{c}438 \\
0.130\end{array}$ & $\begin{array}{c}468 \\
0.267\end{array}$ & $\begin{array}{c}500 \\
0.133\end{array}$ & $\begin{array}{c}384 \\
0.256\end{array}$ & $\begin{array}{c}468 \\
0.591\end{array}$ \\
\hline
\end{tabular}

Notes: Standard errors in parentheses. Lags of capacity additions and retirements are included in the regressions but now shown in the Table. $p$-values are reported as follows: $* p<0.10$, ** $p<0.05$, *** $p<0.01$. Constants are not reported.

The own price elasticity of natural gas-fired combined cycle investment is significantly negative under liberalized wholesale markets (Table 3). In common with our state level estimates, we find some evidence of emission control laws negatively impacting natural gas-fired combined cycle investment, but we have to bear in mind that due to the recency of regulation this might be spurious.

The results for wind power are similar in all estimations. Gas price increases in liberalized wholesale markets result in more wind power, while increases in coal prices result in less. As investment in wind generators were mostly driven by federal production tax credits and state RPSs, the relationship found with coal prices might be an artifact. In contrast to the state level regressions, the coefficients on the expected price for ISO/RTO level nuclear generators are significant under regulated markets. We find a positive cross price elasticity for gas. This signals that once they were allowed as baseload plants, gas power plants tended to displace nuclear power. Nuclear power and coal investment show a similar pattern throughout the 1970s and early 1980s. The structural break of 1979 is significant, showing higher construction rates pre-1979 than afterwards. 
Table 4: ISO/RTO level estimates using expected fuel prices and EIA lead times (plus one year of planning time), see Equation (2).

\begin{tabular}{|c|c|c|c|c|c|c|c|c|}
\hline ISO/RTO level & $\begin{array}{l}(1) \\
\text { csc_fb }\end{array}$ & $\begin{array}{l}(2) \\
\text { csc_pc }\end{array}$ & $\begin{array}{c}(3) \\
\text { csc_sub }\end{array}$ & $\begin{array}{c}\text { (4) } \\
\text { csc_sup }\end{array}$ & $\begin{array}{l}(5) \\
\text { ngfcc }\end{array}$ & $\begin{array}{c}(6) \\
\text { ngfet }\end{array}$ & $\begin{array}{l}\text { (7) } \\
\text { nuc }\end{array}$ & $\begin{array}{l}\text { (8) } \\
\text { owt }\end{array}$ \\
\hline $\begin{array}{l}\text { Liberalized wholesale } \\
\text { markets (PLIB) }\end{array}$ & $\begin{array}{l}-0.31 \\
(1.17)\end{array}$ & $\begin{array}{l}-4.55 \\
(2.72)\end{array}$ & $\begin{array}{l}-1.41 \\
(1.71)\end{array}$ & $\begin{array}{c}-3.30 * * \\
(1.55)\end{array}$ & $\begin{array}{l}-2.48 \\
(2.07)\end{array}$ & $\begin{array}{l}-1.57 \\
(2.54)\end{array}$ & $\begin{array}{l}-1.69 \\
(1.89)\end{array}$ & $\begin{array}{l}-1.54 \\
(2.01)\end{array}$ \\
\hline $\begin{array}{l}\text { Lagged } \ln \text { av. expected } \\
\text { coal price }\end{array}$ & $\begin{array}{c}0.28 \\
(0.64)\end{array}$ & $\begin{array}{c}-3.09 * * * \\
(0.99)\end{array}$ & $\begin{array}{l}-1.48 \\
(0.89)\end{array}$ & $\begin{array}{l}-0.95 \\
(0.56)\end{array}$ & $\begin{array}{l}-0.70 \\
(1.46)\end{array}$ & $\begin{array}{l}-0.65 \\
(0.61)\end{array}$ & $\begin{array}{c}-4.83 * * \\
(1.97)\end{array}$ & $\begin{array}{l}-1.87 \\
(1.25)\end{array}$ \\
\hline $\begin{array}{l}\text { Lagged ln av. expected } \\
\text { gas price }\end{array}$ & $\begin{array}{l}1.21^{*} \\
(0.61)\end{array}$ & $\begin{array}{c}1.99 * * * \\
(0.62)\end{array}$ & $\begin{array}{l}1.56^{* *} \\
(0.63)\end{array}$ & $\begin{array}{l}1.37 * * \\
(0.64)\end{array}$ & $\begin{array}{c}-2.23 * * \\
(0.92)\end{array}$ & $\begin{array}{c}-1.93 * * * \\
(0.47)\end{array}$ & $\begin{array}{l}1.66^{* *} \\
(0.76)\end{array}$ & $\begin{array}{c}0.70 \\
(0.71)\end{array}$ \\
\hline $\begin{array}{l}\text { Lagged } \ln \text { av. expected } \\
\text { coal price*PLIB }\end{array}$ & $\begin{array}{l}-0.95 \\
(0.68)\end{array}$ & $\begin{array}{c}-3.93 * * \\
(1.66)\end{array}$ & $\begin{array}{c}-2.32 * * * \\
(0.56)\end{array}$ & $\begin{array}{l}-1.87 \\
(1.38)\end{array}$ & $\begin{array}{l}-0.35 \\
(2.15)\end{array}$ & $\begin{array}{l}-1.82 \\
(1.17)\end{array}$ & $\begin{array}{c}0.49 \\
(1.01)\end{array}$ & $\begin{array}{l}-3.09 \\
(2.23)\end{array}$ \\
\hline $\begin{array}{l}\text { Lagged } \ln \text { av. expected } \\
\text { gas price*PLIB }\end{array}$ & $\begin{array}{c}0.56 \\
(0.75)\end{array}$ & $\begin{array}{l}5.12 * * \\
(2.17)\end{array}$ & $\begin{array}{l}2.27 * \\
(1.11)\end{array}$ & $\begin{array}{l}3.19^{*} \\
(1.63)\end{array}$ & $\begin{array}{c}0.70 \\
(1.86)\end{array}$ & $\begin{array}{c}1.78 \\
(1.73)\end{array}$ & $\begin{array}{c}0.75 \\
(1.19)\end{array}$ & $\begin{array}{c}2.80 \\
(1.81)\end{array}$ \\
\hline $\begin{array}{l}\text { Lagged ln av. GDP } \\
\text { growth }\end{array}$ & $\begin{array}{c}2.61 \\
(2.98)\end{array}$ & $\begin{array}{l}-2.00 \\
(6.92)\end{array}$ & $\begin{array}{l}-3.92 \\
(5.04)\end{array}$ & $\begin{array}{l}7.80^{*} \\
(4.34)\end{array}$ & $\begin{array}{c}32.84 * * * \\
(7.24)\end{array}$ & $\begin{array}{c}16.29 * * * \\
(4.73)\end{array}$ & $\begin{array}{c}3.94 \\
(9.20)\end{array}$ & $\begin{array}{c}17.17 * * \\
(6.46)\end{array}$ \\
\hline $\begin{array}{l}\text { Lagged Environmental } \\
\text { Laws }\end{array}$ & $\begin{array}{l}-0.22 \\
(0.29)\end{array}$ & $\begin{array}{l}-0.37 \\
(0.60)\end{array}$ & $\begin{array}{c}0.16 \\
(0.43)\end{array}$ & $\begin{array}{l}-0.71 \\
(0.47)\end{array}$ & $\begin{array}{l}-0.58 \\
(0.53)\end{array}$ & $\begin{array}{c}0.44 \\
(0.79)\end{array}$ & $\begin{array}{c}0.38 \\
(0.39)\end{array}$ & $\begin{array}{c}0.58 \\
(1.20)\end{array}$ \\
\hline Time trend & $\begin{array}{c}0.03 \\
(0.02)\end{array}$ & $\begin{array}{c}-0.10^{* *} \\
(0.04)\end{array}$ & $\begin{array}{l}-0.05 \\
(0.03)\end{array}$ & $\begin{array}{l}-0.01 \\
(0.02)\end{array}$ & $\begin{array}{l}-0.01 \\
(0.04)\end{array}$ & $\begin{array}{l}-0.03 \\
(0.02)\end{array}$ & $\begin{array}{c}-0.16^{* *} \\
(0.08)\end{array}$ & $\begin{array}{c}0.03 \\
(0.03)\end{array}$ \\
\hline \multicolumn{9}{|c|}{ Liberalized Wholesale Market Coefficients } \\
\hline $\begin{array}{l}\text { Lagged } \ln \text { av. expected } \\
\text { gas price }\end{array}$ & 1.77 & $7.10 * *$ & $3.84 * * *$ & $4.57 * *$ & -1.53 & -0.15 & $2.41^{*}$ & $3.50^{* *}$ \\
\hline $\begin{array}{l}\text { Lagged } \ln \text { av. expected } \\
\text { coal price }\end{array}$ & -0.67 & $-7.02 * * *$ & $-3.80 * * *$ & -2.81 & -1.06 & $-2.46^{*}$ & $-4.35 * *$ & $-4.96^{* *}$ \\
\hline $\begin{array}{l}\text { Lagged ln capacity } \\
\text { additions }\end{array}$ & Yes & Yes & Yes & Yes & Yes & Yes & Yes & Yes \\
\hline $\begin{array}{l}\text { Lagged ln capacity } \\
\text { retirements }\end{array}$ & Yes & Yes & Yes & Yes & Yes & Yes & Yes & Yes \\
\hline $\begin{array}{l}\text { Planning \& lead times/ } \\
\text { (\#Lags) }\end{array}$ & 5 & 5 & 5 & 5 & 4 & 3 & 7 & 4 \\
\hline $\mathrm{N}$ & 361 & 361 & 361 & 361 & 387 & 414 & 311 & 387 \\
\hline adj. Rsq. & 0.061 & 0.183 & 0.148 & 0.092 & 0.258 & 0.155 & 0.232 & 0.560 \\
\hline
\end{tabular}

Notes: Standard errors in parentheses. Lags of capacity additions and retirements are included in the regressions but now shown in the Table. $p$-values are reported as follows: $* p<0.10, * * p<0.05, * * * p<0.01$. Constants are not reported.

\section{Estimates with EIA expected fuel prices}

There are only minor differences in our findings using expected prices (Table 4), compared to actual prices (Table 3). The coefficient on the wholesale liberalization dummy is not significant for most coal technologies, save for supercritical coal plants. We find a negative and significant own price elasticity for pulverized coal and subcritical coal plants in liberalized markets. The own price elasticity of natural gas combined cycle investment and natural gas combustion turbines is negative and significant in regulated markets. The coefficients of emission control are not significant, unlike in Table 3.

\section{Energy-only vs. capacity markets}

The question whether capacity markets or energy-only markets provide different incentives for investment generation is an important one. Competitive wholesale markets are often plagued by the "missing-money problem" (DOE, 2017), when market revenues without shortage pricing are insufficient to cover the costs of (especially) reserve capacity. Price caps further exacerbate this 
problem. As a consequence, most wholesale markets in the U.S. apply some sort of shortage pricing. Four ISO/RTOs (ISONE, NYISO, PJM, and MISO) introduced centralized capacity markets and mandatory or voluntary auctions (DOE, 2017).

Should energy-only markets without capacity markets support lower levels of investment, we would see a lower fixed effect for ERCOT, CAISO, and SPP than for other regions. The ERCOT fixed effect (base state is AL) is positive for coal technologies but not significant at the 5\% level. Other ISOs show higher (e.g. MISO) or even negative (CAISO) effects. The ERCOT fixed effect for natural gas-fired technologies and onshore wind turbines is positive and significant, but lower than for MISO or SPP, for example, but higher than NYISO or ISONE. The SPP fixed effect is positive for all technologies and significant for natural gas generators, onshore wind turbines, fluidized bed, and subcritical coal investments. Unlike the other regions, the CAISO fixed effect is negative (yet not significant) for all types of coal and nuclear generators and positive for natural gas and wind investment. While these fixed effects give us the pattern of investments within an ISO/RTO, we do not find particular patterns of underinvestment in markets without organized capacity markets.

\section{DISCUSSION AND CONCLUSIONS}

We investigated the drivers of power generation investments before and after wholesale market restructuring in the United States. We find that electricity market deregulation at the wholesale level resulted in significant immediate investment in natural gas baseload technologies due to higher expected profits, and in decreased investment in coal technologies, although high efficiency baseload coal generation was less negatively, or not impacted. Price expectations can explain the surge in natural gas plants in competitive wholesale markets, as mid-range price expectations tended to move below realized prices in the past two decades.

We find negative own fuel price elasticities for most forms of coal and natural gas baseload investments after wholesale market restructuring, while prices do not play such a strong role in rate-of-return markets. We also find that natural gas prices tend to result in reduced investments in natural gas technologies but in increased generation capacity in all forms of coal and wind turbine technologies. In competitive wholesale markets, natural gas prices tend to set the marginal price, resulting in a relatively larger marginal profit especially for renewables that operate at zero marginal cost. The EIA (2016e) projects falling generation from coal-fired electricity in the coming decades, with limited capacity additions, partly due to emission regulations and to low natural gas prices. We find that high natural gas price expectations in the future could shift generation investment in both renewable or other non-natural gas fired baseload technologies.

While electricity demand stayed flat in recent years and only incremental increases are forecasted (EIA, 2016e), around $40 \mathrm{GW}$ of especially coal and nuclear baseload plants originating from the 1960s and 1970s are likely to be retired in the coming decade (DOE, 2017). A former wave of retirements in the early 2010 s coincided with several environmental regulations on emissions control (DOE, 2017). The main question, therefore, is, what these retiring plants are going to be replaced with?

Our study shows that when natural gas prices fall, investments in coal power plants decline. The DOE (2017) currently sees little chance of rising natural gas prices, even though periodical or regional hikes and differences can be expected. The DOE (2017) also notes that no new coal plants have been built since 2014 due to their unfavorable economics compared to gas-fired plants. In the past 15 years, electricity prices in liberalized wholesale markets tended to follow natural gas prices, driven by natural gas peak loaders. Due to the low prices of the past years, often technologies that 
previously provided baseload power are forced to the mid-range of the ladder (DOE, 2017). We find that price expectations clearly drive investment choices in liberalized wholesale markets but less so in rate-of-return regulated markets.

Wind and solar investments have been driven by the rapidly declining cost of technology on the one hand and by production tax credits and other supportive policies on the other hand. Nonetheless, we find that wind turbine investments increase with higher natural gas prices in liberalized wholesale markets, as the marginal profit of wind generators has been the greatest in the past when gas prices were higher.

While natural gas price expectations bear much less significance in rate-of-return markets, we believe that consistently and permanently rising natural gas prices would shift generation towards primarily renewable energies, but also towards other fossil fuel generators, or at least would delay the closure of such generators, despite the EPA's environmental and emission requirements.

In summary, we show that market deregulation has a significant impact on the choice of electricity investment. In regulated cost-of-service markets fuel prices have generally less impact on the choice of the plant built, while in liberalized wholesale markets natural gas price expectations significantly impact on all forms of investment. Natural gas supply and prices, therefore, have the potential to significantly shape the power generation landscape of states with liberalized wholesale electricity markets in the future.

\section{ACKNOWLEDGMENTS}

We thank the Australian Research Council for funding under Discovery Project DP160100756 "Energy Efficiency Innovation, Diffusion and the Rebound Effect." We thank William Booth, Paul Burke, Ayaka Jones, Jeff Kessler, Joshua Rhodes, and four anonymous referees for very useful insights and comments. We also thank seminar participants at the Department of Economics at the University of Sydney for useful comments.

\section{REFERENCES:}

Averch, H. and L.L. Johnson (1962). "Behavior of the Firm under Regulatory Constraint." American Economic Review 52: 1053-1069. https://doi.org/10.7249/P2488-1.

Bloom, N., S. Bond, and J. van Reenen (2007). "Uncertainty and Investment Dynamics.” Review of Economic Studies 74: 391-415. https://doi.org/10.1111/j.1467-937X.2007.00426.x.

Borenstein, S. (2000). "Understanding Competitive Pricing and Market Power in Wholesale Electricity Markets." Electricity Journal 13(6): 49-57. https://doi.org/10.1016/S1040-6190(00)00124-X.

Borenstein, S. and J.B. Bushnell (2015). “The U.S. Electricity Industry After 20 Years of Restructuring.” The Annual Review of Economics 7: 437-463. https://doi.org/10.1146/annurev-economics-080614-115630.

Bushnell, J.B. (2004). “California's Electricity Crisis: A Market Apart?” Energy Policy 32: 1045-1052. https://doi. org/10.1016/j.enpol.2003.11.003.

Caballero, R.J. and R.S. Pindyck (1996). “Uncertainty, Investment, and Industry Evolution.” International Economic Review 37(3): 641-662. https://doi.org/10.2307/2527445.

California Public Utilities Commission (2007). "PUC Sets GHG Emissions Performance Standard to Help Mitigate Climate Change." http://docs.cpuc.ca.gov/published/News_release/63997.htm, accessed on 20 September 2017

Campbell, R.J. (2013). "Increasing the Efficiency of Existing Coal-Fired Power Plants.” Congressional Research Service 7-5700, R43343.

Covert, T., M. Greenstone, and C.R. Knittel (2016). “Will We Ever Stop Using Fossil Fuels?” Journal of Economic Perspectives 30(1): 117-138. https://doi.org/10.1257/jep.30.1.117.

Craig, J.D. and S.J. Savage (2013). "Market Restructuring, Competition, and the Efficiency of Electricity Generation: Plantlevel Evidence from the United States 1996 to 2006." The Energy Journal 34(1): 1-31. https://doi.org/10.1016/03605442(80)90046-8. 
Csereklyei, Z. (2014). “Measuring the Impact of Nuclear Accidents on Energy Policy.” Ecological Economics 99: 121-129. https://doi.org/10.1016/j.ecolecon.2014.01.010.

Csereklyei, Z., P.W. Thurner, A. Bauer, and H. Kuechenhoff (2016). "The Effect of Economic Growth, Oil Prices, and the Benefits of Reactor Standardization: Duration of Nuclear Power Plant Construction Revisited.” Energy Policy 91: 49-59. https://doi.org/10.1016/j.enpol.2015.12.032.

Davis, L.W. and C. Wolfram (2012). "Deregulation, Consolidation, and Efficiency: Evidence from U.S. Nuclear Power." American Economic Journal: Applied Economics 4(4): 194-225. https://doi.org/10.1257/app.4.4.194.

Dechert, W.D. (1984). "Has the Averch-Johnson Effect Been Theoretically Justified?" Journal of Economic Dynamics and Control 8(1): 1-17. https://doi.org/10.1016/0165-1889(84)90036-8.

DOE (2017). "Staff Report to the Secretary on Electricity Markets and Reliability, U.S. Department of Energy." U.S. Department of Energy, August 2017, https://energy.gov/downloads/download-staff-report-secretary-electricity-markets-andreliability

EIA (2004). “Annual Energy Outlook.” U.S. Energy Information Administration. https://polar.mephi.ru/ru/projects/ international_energy_outlook/2004_Annual_Energy_Outlook.pdf.

EIA (2014). "State Energy Data System, Price and Expenditure Technical Notes.” U.S. Energy Information Administration. https://www.eia.gov/state/seds/.

EIA (2016a). Form 860-Y2014, Annual Electric Generator Data, U.S. Energy Information Administration. https://www.eia. gov/electricity/data/eia860/.

EIA (2016b). "Levelized Cost and Levelized Avoided Cost of New Generation Resources in the Annual Energy Outlook 2016.” U.S. Energy Information Administration. http://www.eia.gov/outlooks/aeo/electricity_generation.cfm

EIA (2016c). “Average Utilization for Natural Gas Combined-Cycle Plants Exceeded Coal Plants in 2015.” U.S. Energy Information Administration. http://www.eia.gov/todayinenergy/detail.php?id=25652

EIA (2016d). "Demand Trends, Prices, and Policies Drive Recent Electric Generation Capacity Additions." U.S. Energy Information Administration. http://www.eia.gov/todayinenergy/detail.php?id=25432

EIA (2016e). “Annual Energy Outlook 2016.” U.S. Energy Information Administration. https://www.eia.gov/outlooks/aeo/ anwr.php.

EIA (various years). “Annual Energy Outlook.” (DOE/EIA-0383), U.S. Energy Information Administration, each year from 1979 to 2014 taken from the archives, accessed on 30.7.2017 at: https://www.eia.gov/outlooks/aeo/archive.php

Fabrizio, K., N.L. Rose, and C. Wolfram (2007). "Do Markets Reduce Costs? Assessing the Impact of Regulatory Restructuring on U.S. Electric Generation Efficiency.” American Economic Review 97: 1250-1277. https://doi.org/10.1257/ aer.97.4.1250.

FERC (1999). The United States of America, Federal Energy Regulatory Commission, 18CFR, Part 35, Docket No. RM99-2000; Order No. 2000, Issued December 20, 1999.

Fleten, S.E., E. Haugom, and C.J. Ullrich (2017). "The Real Options to Shutdown, Startup, and Abandon: U.S. Electricity Industry Evidence.” Energy Economics 63: 1-12. https://doi.org/10.1016/j.eneco.2017.01.016.

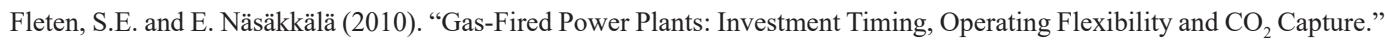
Energy Economics 32: 805-816. https://doi.org/10.1016/j.eneco.2009.08.003.

Flyvbjerg, B. (2014). "What You Should Know about Megaprojects and Why: An Overview.” Project Management Journal 45(2): 6-19. https://doi.org/10.1002/pmj.21409.

Hamilton, J.D. (2009). “Understanding Crude Oil Prices.” The Energy Journal 30(2): 179-206. https://doi.org/10.5547/ ISSN0195-6574-EJ-Vol30-No2-9.

IEA (2014). "Energy Policies of IEA Countries: The United States.” The International Energy Agency, Paris. http://www.iea. org/Textbase/npsum/US2014sum.pdf.

Joskow, P.L. (2001). “California's Electricity Crisis.” Oxford Review of Economic Policy 17(3): 365-388. https://doi. org/10.1093/oxrep/17.3.365.

Joskow, P.L. (2003). “Energy Policies and Their Consequences After 25 Years.” The Energy Journal 24(4): 17-49. https://doi. org/10.5547/ISSN0195-6574-EJ-Vol24-No4-2.

Joskow, P.L. (2008). "Lessons Learned from Electricity Market Liberalization.” The Energy Journal 29(SI2): 9-42. https:// doi.org/10.5547/ISSN0195-6574-EJ-Vol29-NoSI2-3.

Joskow, P.L. (2011). "Comparing the Costs of Intermittent and Dispatchable Electricity Generating Technologies.” American Economic Review 101(3): 238-241. https://doi.org/10.1257/aer.101.3.238.

Knittel, C.R., K. Metaxoglou, and A. Trindade (2015). "Natural Gas Prices and Coal Displacement: Evidence from Electricity Markets.” NBER Working Paper No. 21627. https://doi.org/10.3386/w21627.

Law, S.M. (2014). “Assessing the Averch-Johnson-Wellisz Effect for Regulated Utilities.” International Journal of Economics and Finance 6(8): 41-67. https://doi.org/10.5539/ijef.v6n8p41.

All rights reserved. Copyright $(C 2018$ by the IAEE. 
Lazard (2016). Lazard's Levelized Cost of Energy Analysis-Version 10.0, December 2016, Lazard. https://www.lazard. com/media/438038/levelized-cost-of-energy-v100.pdf.

Ley, M., T. Stucki, and M. Woerter (2016). “The Impact of Energy Prices on Green Innovation.” The Energy Journal 37(1): 41-75. https://doi.org/10.5547/01956574.37.1.mley.

Morey, M.J. and L.D. Kirsch (2016). "Retail Choice in Electricity: What Have We Learned in 20 Years?” Electric Markets Research Foundation, Christensen Associates Energy Consulting LLC.

Newell, R.G., A.B. Jaffe, and R.N. Stavins (1999). "The Induced Innovation Hypothesis and Energy-Saving Technological Change." The Quarterly Journal of Economics 114(3): 941-975. https://doi.org/10.1162/003355399556188.

Popp, D. (2002). "Induced Innovation and Energy Prices.” The American Economic Review 92(1): 160-180. https://doi. org/10.1257/000282802760015658.

Rhodes, J.D., C.W. King, G. Gülen, S.M. Olmstead, J.S. Dyer, R.E. Hebner, F.C. Beach, T.F. Edgar, and M.E. Webber (2016). “A Geographically Resolved Method to Estimate Levelized Power Plant Costs with Environmental Externalities." White Paper UTEI/2016-04-1, 2016, available at http://energy.utexas.edu/the-full-cost-of-electricity-fce/.

Timmermann, A. and C.W.J. Granger (2004) "Efficient Market Hypothesis and Forecasting." International Journal of Forecasting 20: 15-27. https://doi.org/10.1016/S0169-2070(03)00012-8.

Warwick, W.M. (2002). "A Primer on Electric Utilities, Deregulation, and Restructuring of U.S. Electricity Markets.” Prepared for the U.S. Department of Energy Federal Energy Management Program under Contract DE-AC06-76RLO 1830.

Wolfram, C. (2005). "The Efficiency of Electricity Generation in the U.S. after Restructuring,” In Electricity Deregulation: Choices and Challenges. Ed: J. Griffin and S. Puller. University of Chicago Press. 227-255. https://doi.org/10.7208/chicago/9780226308586.003.0006.

Yeh, S. and E.S. Rubin (2007). "A Centurial History of Technological Change and Learning Curves for Pulverized Coal-Fired Utility Boilers.” Energy 32: 1996-2005. https://doi.org/10.1016/j.energy.2007.03.004. 


\section{APPENDIX}

Table A1: State-level estimates using expected fuel prices and Lazard (2016) lead times (plus one year planning time), see Equation (2).

\begin{tabular}{|c|c|c|c|c|c|}
\hline Lazard's Construction Times & (1) & (2) & (3) & (4) & $(5)$ \\
\hline State Level & csc_fb & csc_pc & csc_sub & csc_sup & owt \\
\hline $\begin{array}{l}\text { Liberalized wholesale } \\
\text { markets (PLIB) }\end{array}$ & $\begin{array}{l}1.68^{*} \\
(0.96)\end{array}$ & $\begin{array}{c}-2.32 * * \\
(0.90)\end{array}$ & $\begin{array}{c}0.87 \\
(1.42)\end{array}$ & $\begin{array}{c}-1.33^{*} \\
(0.78)\end{array}$ & $\begin{array}{c}-2.16^{*} \\
(1.18)\end{array}$ \\
\hline $\begin{array}{l}\text { Lagged ln av. expected coal } \\
\text { price }\end{array}$ & $\begin{array}{c}0.81 * * \\
(0.39)\end{array}$ & $\begin{array}{l}-1.00 \\
(0.73)\end{array}$ & $\begin{array}{c}0.03 \\
(0.88)\end{array}$ & $\begin{array}{c}-0.63^{* *} \\
(0.30)\end{array}$ & $\begin{array}{c}-1.52 * * \\
(0.62)\end{array}$ \\
\hline $\begin{array}{l}\text { Lagged ln av. expected gas } \\
\text { price }\end{array}$ & $\begin{array}{c}0.36 \\
(0.38)\end{array}$ & $\begin{array}{l}-0.09 \\
(0.29)\end{array}$ & $\begin{array}{c}0.54 \\
(0.42)\end{array}$ & $\begin{array}{l}-0.00 \\
(0.19)\end{array}$ & $\begin{array}{c}1.59 * * * \\
(0.58)\end{array}$ \\
\hline $\begin{array}{l}\text { Lagged ln av. expected coal } \\
\text { price*PLIB }\end{array}$ & $\begin{array}{c}-1.54 * * \\
(0.72)\end{array}$ & $\begin{array}{c}-1.77 * * \\
(0.83)\end{array}$ & $\begin{array}{c}-2.13 * * \\
(0.86)\end{array}$ & $\begin{array}{l}-0.84^{*} \\
(0.47)\end{array}$ & $\begin{array}{l}-0.32 \\
(0.88)\end{array}$ \\
\hline $\begin{array}{l}\text { Lagged ln av. expected gas } \\
\text { price*PLIB }\end{array}$ & $\begin{array}{l}-0.58 \\
(0.62)\end{array}$ & $\begin{array}{l}2.44 * * * \\
(0.69)\end{array}$ & $\begin{array}{c}0.29 \\
(0.79)\end{array}$ & $\begin{array}{l}1.30 * * \\
(0.61)\end{array}$ & $\begin{array}{c}1.73 \\
(1.06)\end{array}$ \\
\hline Lagged ln av. GDP growth & $\begin{array}{l}-4.26 \\
(2.85)\end{array}$ & $\begin{array}{c}0.89 \\
(2.70)\end{array}$ & $\begin{array}{l}-6.92^{*} \\
(4.11)\end{array}$ & $\begin{array}{l}3.78^{*} \\
(1.99)\end{array}$ & $\begin{array}{c}9.03 * * * \\
(3.25)\end{array}$ \\
\hline Lagged Environmental Laws & $\begin{array}{l}-0.03 \\
(0.18)\end{array}$ & $\begin{array}{c}0.26 \\
(0.36)\end{array}$ & $\begin{array}{c}0.37 \\
(0.35)\end{array}$ & $\begin{array}{l}-0.09 \\
(0.16)\end{array}$ & $\begin{array}{c}0.97 \\
(0.91)\end{array}$ \\
\hline Time trend & $\begin{array}{c}0.02 \\
(0.01)\end{array}$ & $\begin{array}{c}-0.08 * * * \\
(0.02)\end{array}$ & $\begin{array}{l}-0.04 \\
(0.03)\end{array}$ & $\begin{array}{r}-0.04^{*} \\
(0.02)\end{array}$ & $\begin{array}{c}0.05^{* *} \\
(0.02)\end{array}$ \\
\hline \multicolumn{6}{|c|}{ Liberalized Wholesale Market Coefficients } \\
\hline $\begin{array}{l}\text { Lagged ln av. expected gas } \\
\text { price }\end{array}$ & -0.22 & $2.34 * * *$ & 0.83 & $1.30^{* *}$ & $3.32 * * *$ \\
\hline $\begin{array}{l}\text { Lagged } \ln \text { av. expected coal } \\
\text { price }\end{array}$ & -0.73 & $-2.77 * * *$ & $-2.10 * * *$ & $-1.47 * *$ & $-1.84 * *$ \\
\hline Lagged ln capacity additions & Yes & Yes & Yes & Yes & Yes \\
\hline $\begin{array}{l}\text { Lagged ln capacity } \\
\text { retirements }\end{array}$ & Yes & Yes & Yes & Yes & Yes \\
\hline $\begin{array}{l}\text { Planning \& lead times/ } \\
\text { (\#Lags) }\end{array}$ & 6 & 6 & 6 & 6 & 2 \\
\hline $\mathrm{N}$ & 592 & 592 & 592 & 592 & 847 \\
\hline adj. Rsq. & 0.022 & 0.048 & 0.064 & 0.047 & 0.309 \\
\hline
\end{tabular}

Notes: Standard errors in parentheses. Lags of capacity additions and retirements are included in the regressions but now shown in the Table. $p$-values are reported as follows: $* p<0.10, * * p<0.05, * * * p<0.01$. Constants are not reported. 